\title{
Kernos
}

Revue internationale et pluridisciplinaire de religion grecque antique

30 | 2017

Varia

\section{Religious discourse in Hellenistic and Roman times: content topoi in Greek epigraphic cult foundations and sacred norms}

\section{María-Paz de Hoz}

\section{Q OpenEdition \\ 1 Journals}

\section{Electronic version}

URL: http://journals.openedition.org/kernos/2496

DOI: $10.4000 /$ kernos.2496

ISSN: 2034-7871

\section{Publisher}

Centre international d'étude de la religion grecque antique

\section{Printed version}

Date of publication: 1 October 2017

Number of pages: $187-220$

ISSN: 0776-3824

\section{Electronic reference}

María-Paz de Hoz, «Religious discourse in Hellenistic and Roman times: content topoi in Greek epigraphic cult foundations and sacred norms », Kernos [Online], 30 | 2017, Online since 01 October 2019, connection on 18 September 2020. URL : http://journals.openedition.org/kernos/2496 ; DOI : https://doi.org/10.4000/kernos.2496

This text was automatically generated on 18 September 2020 .

Kernos 


\title{
Religious discourse in Hellenistic and Roman times: content topoi in Greek epigraphic cult foundations and sacred norms
}

\author{
María-Paz de Hoz
}

This paper has been realized with financial support of the Spanish Ministry of Science and Innovation (Project: Hellenization in the Greco-Roman East: processes of assimilation and perception in the local cultures: FFI2015-63956-P). For the abbreviations used for the inscriptions mentioned see list in $p .217$. I would like to thank the anonymous referee for his comments and suggestions, which have improved the final version.

\section{Introduction}

1 The fact that ancient and modern studies on rhetoric of religion focus on hymns is very understandable because hymns include the main elements in any communication with the gods. ${ }^{1}$ They include acclamation and praise to the gods with different elements and special topoi, and they include prayer, often based on arguments related to, or exposed in, the preceding praise. But besides hymns, religious content topoi can be found in other sacred texts written in prose from Hellenistic and Roman times. ${ }^{2}$

My intention here is to analyze some texts dealing with private foundations of cults or with sacred regulations that share common topoi, and to compare them with hymnic rhetoric of the same period and, in a lesser degree, with legal and philosophical texts. The first aim is to identify old and new elements that are recognized by the community and by the gods as influential and persuasive, and the second aim is to identify the main conceptual elements in the religious discourse of Hellenistic and Roman times.

2 The earliest text concerning a sacred foundation analysed here is Artemidorus' cult foundation in Thera (ATh), dated to the third century BC. Artemidorus, coming from Perge in Minor-Asiatic Pamphilia, erects a cult funerary foundation in Thera where 
different divinities are joined together: divinities of the city, personal gods and abstractions. ${ }^{3}$ Belonging to the same time or not much later is the so-called Delian aretalogy of Sarapis (SD). The priest Apollonius relates, late in the third century BC or beginning of the second, how he erected, following the instructions of Sarapis, a temple for the god in Delos, and how he won over the people who tried to avoid the building of the temple thanks to a miracle of the god. ${ }^{4}$ As thanksgiving to the god, a verse hymn praising him follows the prose report, and tells the same event in a much more elaborated text. More than 150 years later, in the middle and during the second half of the first century BC, Antiochus I of Commagene commissioned a group of texts announcing the foundation of his funerary cult monument. ${ }^{5} \mathrm{~A}$ very long inscription written on the back of huge thrones for himself and other divinities states his reasons for building a hierothesion (funerary cult monument) and founding a cult ritual in his honour to commemorate yearly his death (N). It also includes a hieros nomos to be observed by all persons participating in the cult ritual. Other shorter but related inscriptions were placed along the processional way from the city of Arsameia up to the hierothesion on the summit of an artificial tumulus built over the Nemrud Dagi ( $\mathrm{Np}$ will be mentioned here). Furthermore, another two hierothesia and up to eleven temenos sites have been discovered, most of them with inscriptions. The hierothesion from Arsameia on the Nymphaion (A), dedicated to Mithradates I Kallinikos and Antiochus self, and the text in the temenos of Ancoz (Anz) will also be analysed here, since they includes some interesting elements that do not appear in $\mathrm{N}$ or Np. ${ }^{6}$ Antiochus establishes his own cult adding it to the cult of important syncretic divinities that reflect the Greek-Anatolian-Persian symbiosis of late Hellenistic times, especially in the area of Asia Minor and Syria. ${ }^{7}$ The so-called sacred law of Philadelphia ( $\left.\mathrm{Ph}\right)$ is a regulation transmitted through a dream by Zeus to a certain Dionysius, establishing a series of ethical norms of behaviour that free people, slaves, men and women had to respect in order to enter Dionysius' oikos (a cult association or a private sanctuary). ${ }^{8}$ The oikos has altars or images (the word is lost) of Zeus and Hestia, all theoi Soteres and different divine personifications, ${ }^{9}$ but the stele with the regulations is set up near the goddess Agdistis, guardian of the oikos. The inscription is dated to the end of the second or beginning of the first century BC. The testament of Epikrates(EM) is a long inscription with instructions concerning the funerary consecration of a territory. The sacred nature of this text is due to the fact that the foundation is made by divine command of Epikrates' son turned into divine hero after his dead, and that his grave

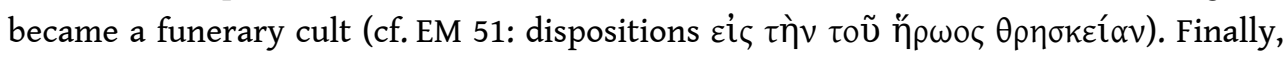
the stele found in Mygdonia (Macedonia) concerning a cult foundation for Sarapis in Locrian Opous (SO), though fragmentary, since the upper and lower parts of the stele are unfortunately lost, includes some of the topoi discussed here that correspond to topoi that usually belong to the central part of foundation texts. It is very probable that most of the others were present in the missing sections.

3 Despite the many interesting rhetorical aspects of the formal and stylistic presentation of the texts, especially in the case of the inscriptions of Antiochus and Dionysius, what deserves my attention here is the existence in all inscriptions of a series of content elements and terminology belonging to the same religious conventions. These texts are quite different in the details concerning the foundations and in the way the facts and the regulations are presented. Common to all of them is, however, the intention of persuading both the gods and the worshippers, and the use of divine authority and aretalogy for self-propaganda. Self-propaganda is also the main objective of some 
rhetoric hymns, such as those of Aristides. All these texts use similar religious topoi to stress their divine character, mainly the divine authority of their foundation texts, the relation of the worshippers to the divinity, and the philanthropic nature of the god.

Though not directly addressed to the gods, such as the hymns, but to worshippers, these texts also include praises, acts of piety and respect, and prayers to divine beings, and they are contemporaneous to, or even precede, the earliest evidence of rhetoric in prose hymns.

5 The existence of a proper rhetoric for praises to the gods is already stated in ancient Greek rhetoric treatises. ${ }^{10}$ In the first century AD, Theon mentions this type of rhetoric for the first time as an example of the encomium. The encomium addressed to the gods, he adds, is called a hymn (109). Nevertheless, he does not describe the rhetoric of the hymn, and limits his description to the rhetoric of the encomium to mortals. It is in the second century AD when Alexander, son of Noumenius, describes a specific religious rhetoric by establishing the main topoi of the hymns (Alex., Rh., 4-6). In the third century AD, Menander (1.333-344) establishes the different types of hymns, and how the composer makes use of all these types together. But, significantly, it is in Menander's exposition of the encomium to the emperor (2.368-377) where we find the closest topoi to rhetoric praises to the gods from Hellenistic and Roman times. The first evidence of what is usually considered a rhetoric (prose) hymn, is the Isis aretalogy of Maroneia dated to the first century $\mathrm{BC},{ }^{11}$ the next one being the corpus of Hymns of Aelius Aristides. ${ }^{12}$ Focusing mainly on those treatises and Aelius Aristides' prose hymns, religious rhetoric is the subject of various important papers and books on ancient rhetoric. ${ }^{13}$

6 The topoi of cult foundations and norms will thus be compared with topoi in hymns and aretalogies from the same period in order to stress the main elements of the general religious discourse from Hellenistic times onwards. Main texts for comparison will be the hymnic part of the already mentioned Delian aretalogy (SD); the aretalogy of Isis of Maroneia (IM), dated to the first century BC; other hymns and aretalogies to Isis dating from the first century $\mathrm{BC}$ to the second century $\mathrm{AD}$, such as the aretalogy from Kyme (IK), or Isidorus' hymns (Is.,1-4); and hymns dated to the second century, mainly Aelius Aristides' and the Orphic hymns. ${ }^{14}$ Besides cult foundations or regulations, and hymns and aretalogies, other religious texts include one or more of these topoi, depending on the nature and intention of the text, thus demonstrating the expansion of certain religious topoi in this period. ${ }^{15}$ Many of the analyzed texts also share an elevated literary character. Nevertheless, the stylistic aspects of the rhetoric are out of the scope of this paper, as this work is limited to the subject matters as effective elements of the discourse.

7 The texts on cult foundations have a first part focusing on the founder, his identity and his relation to the divinity, and the divine character of his written disposition; a second part focusing on the people with access to the sacred place or association, where the norms of behaviour are stated; and a third part where the main element is the god or gods to whom the foundation or association is consecrated, and who are its protectors and also overseers of the good behaviour of the participants and of the observance of the norms. This last part is expressed through imprecations and prayers where acclamation is the main element in order to praise the god and strengthen the divine nature of the foundation. 
The main topoi that will be analysed here are thus related to the following content elements:

1. Identification of the founder and his relation to the divinity.

2. Statement of the foundation as divine order or advice.

3. Statement of the importance of the written word for securing the maintenance of the cult and the enforcement of the regulations.

4. Information on physical relation between the inscription and the cult foundation.

5. Information on the god whom the foundation is dedicated and other gods who may be associated with the main one.

6. Tradition and innovation in the regulations.

7. Information of worshippers for whom the foundation is erected.

8. Content of the foundation norms: morality, justice, philanthropy.

9. Elements to force the observance of the norms: public confession, oath and imprecations.

10. Acclamations.

11. Prayer.

\section{Identification of the sacral founder and his relation to the divinity}

The name and origin of the founder, and his relation to the divinity appear normally right at the beginning. Apollonius, the priest who built a sanctuary for Sarapis in Delos, begins his aretalogy (SD) to the god stating that his father and grandfather were priests

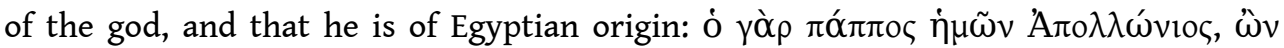

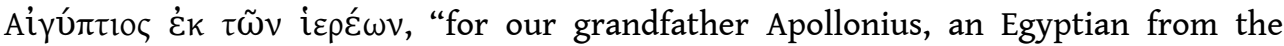

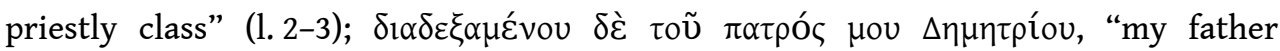
Demetrios, having succeeded" (1. 7-8). ${ }^{16}$ Artemidorus' identity and origin is stated in his

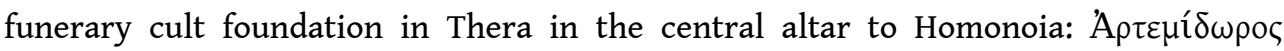

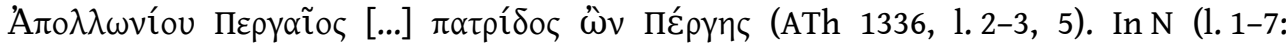

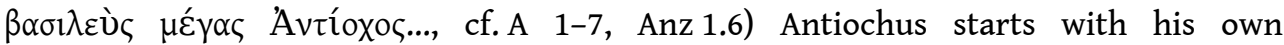
identification as it is proper to a king, followed by all his ancestors and an expression of

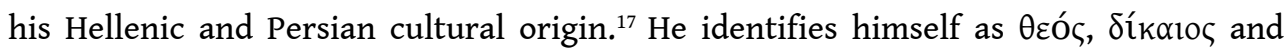
$\dot{\varepsilon} \pi \iota \varphi \alpha \vee \eta ́$. Regarding the founder of the Philadelphia statute we just know his name, Dionysius, and that he is the owner of an oikos, whether this term refers to a physical building or an association ( $\mathrm{Ph} 4-5)$. His Hellenic culture is nevertheless right away clear from the identity of the divine beings whom he dedicates the altars or images in the oikos. The topos of old age as gift from the gods is very appropriate to founders of sacred institutions. Artemidorus of Perge was given by Artemis and Pronoia all together 93 years (IG XII 1350); the Aegyptian grandfather of Apollonius, who introduced Serapis' cult in Delos, lived 97 years (SD 6, cf. 40f.) and also Antiochus of Commagene's long life is mentioned ( $\mathrm{N} 22-23$, cf. Anz 14).

The validation of the founders is also made by referring to personal favours granted to them by the gods. Antiochus declares having been saved from great dangers, and in a

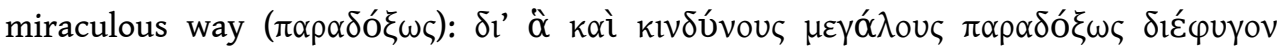
(Antiochus: N 20-21). To be saved from great perils by the god turns into a topos from Hellenistic times onwards, and we find it also in other sort of texts. ${ }^{18}$ In hymns and aretalogies it is very well attested; and miraculous are many of the cures done by 
Asclepius to Aristides. ${ }^{19}$ The miraculous healings of Asclepius constitute in fact the best evidence of a god's miraculous action, and one of the best evidences of aretalogies. ${ }^{20}$ This miraculous narrative also serves to validate the relationship between the god and the founder in foundation texts, and thus it also serves to validate the cult foundation or the norms.

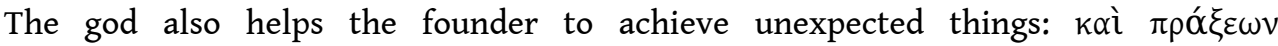

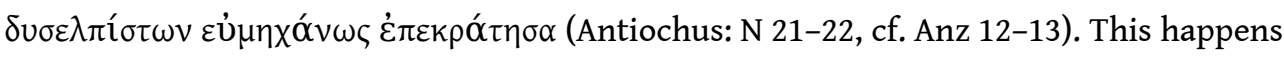
especially in relation to the foundation of the cult: Apollonius achieved to build Sarapis'

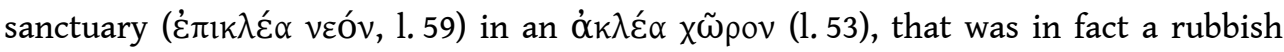
dump; and miraculous is the way he wins the process set by people from Delos against the building of Sarapis' sanctuary (SD 84-92). The fragmentary narrative on the foundation of the Sarapis cult in Locrian Opous includes also the achievement of a difficult enterprise: Xenainetos, who receives the divine dream and command, has to convince Eurynomos, his political enemy, to found the cult (SO 7-9, being this obstacle repeated in 14-15).

Many of these beneficiary acts are done through the $\pi \alpha \rho$ ovoí $\alpha$ of the god. In most cases, this epiphany occurs through dreams (see infra). In Artemidorus' altar to Priapus, this

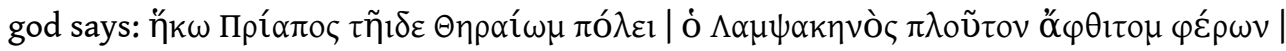

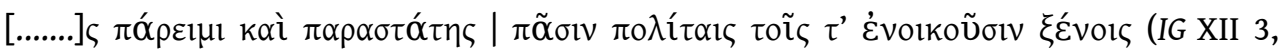
$1335 c-d) .{ }^{21}$ Like in the case of Priapus, who brings enormous richness, the epiphany of the god is in all these cases a philanthropic act, as Pernot has already stated concerning rhetoric hymns; nothing is said, nevertheless, about the physical appearance of the divine being. ${ }^{22}$

When the founder is further described, it is significant that some of his virtues are

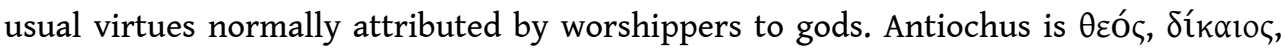

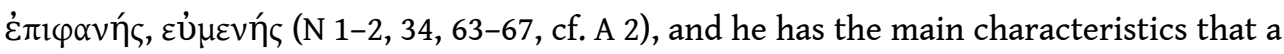
good governor must have, which are connected to the philanthropic beneficiary acts that are expected from the gods: achievement of wealth, peace and happiness for the people, philanthropia, and eumeneia (N 11-20, A 35-56, Anz 9-15). ${ }^{23}$ But what is mostly

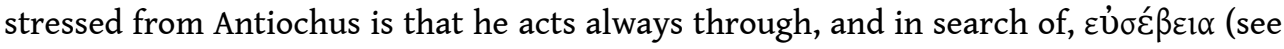

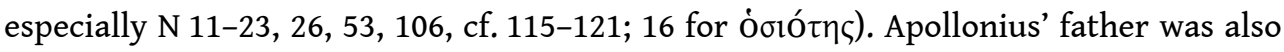
rewarded by Sarapis because of his $\varepsilon \dot{\sigma} \sigma \varepsilon ́ \beta \varepsilon 1 \alpha$ (SD 9, cf. 47-49 concerning Apollonius himself). ${ }^{24}$ This symbiosis between the encomium to the divinity and the encomium to a mortal, and the strategy of praising the mortal through his relation to the divinity finds, a couple of centuries later, its best rhetoric example in Aristides' discourse no. 30 in honor of Apellas. ${ }^{25}$

\section{Statement of the foundation as divine order or advice}

The identification of the founder is immediately related to the mention of the foundation's document. The divine character of the transmitted words constitutes a topos. Artemidorus of Perge erects his cult foundation because of a dream (ATh 1336:

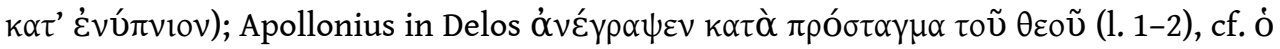

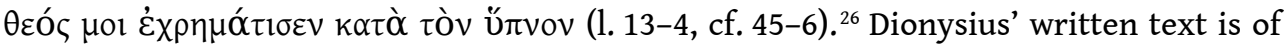
divine origin and has been transmitted to him by Zeus through a dream (1. 2-4; cf. again

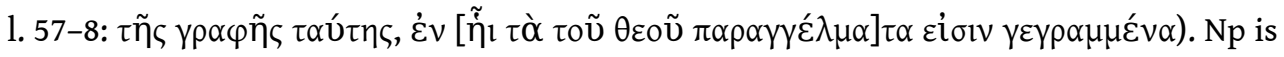


much more literary and emphatic about the divine origin of Antiochus' written text:

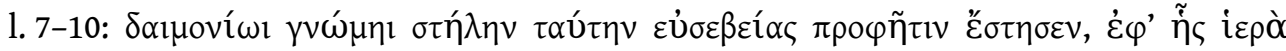

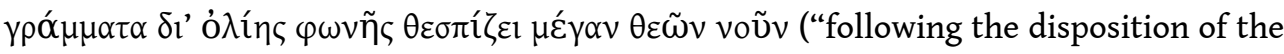
daimones he erected this stele as prophetess of his piety, where sacred letters announce the great will of the gods with low voice"; cf. N 105-122, A 9-13, Anz 7-9, 69-70, 148151). In the narrative of the foundation in Opous, Xenainetos receives a command from Sarapis through a repeated dream to transmit his orders to Eurynomos in Opous (SO 37, 9-10). The identification of Xenainetos was probably included in the upper part of the stele that is missing, and we only know that he was temporarily in Thessalonike (where a cult to Sarapis existed since the third century BC). The god even leaves a letter under his pillow: the proof needed by Eurynomos to believe in the divine command

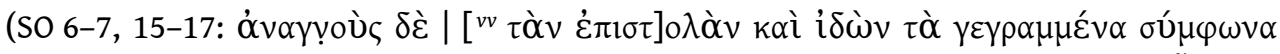

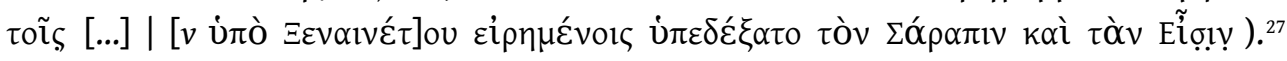
Epikrates from Magnesia of the Sipylus says that the heroes of his son Diophantus have ordered him through dreams, signs and apparitions to consecrate him a great amount of the land specified in the testament (EM 26-36). The divine order as reason of a foundation is a very well known topos that does not need further comment. It belongs to an ancient common worship and belief in the communication with the gods. ${ }^{28}$ Though not in traditional hymns, it is also a topos in some aretalogies ${ }^{29}$ and in the prose rhetoric hymns of Aelius Aristides (Atenea 1) or in his Hieroi logoi (2.2)..$^{30}$

\section{Statement of the importance of the written word for securing the maintenance of the cult and the enforcement of the regulations}

15 Less traditional is the insistence in the written word of sacred texts. This is very important in the inscriptions of Apollonius, Antiochus, Dionysius and Xenainetus. ${ }^{31}$ This insistence is closely related to the idea of the eternity of the cult and of its norms,

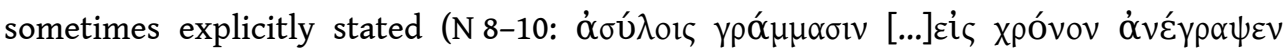
$\alpha i \omega ́ v i o v){ }^{32}$ The importance of eternity, though in this case not in relation to the written word but to the altars, is very much emphasized in Artemidorus' temenos in Thera $(1336,1337,1338,1343,1345)$. See especially the altar to Tyche: Пврүaĩo

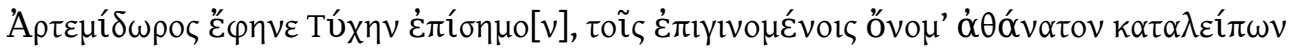
(1338).

Well known in Archaic and Classical literature is the topos, now appropriated by religious rhetoric, of the writer as mere instrument of the god's will and intelligence. ${ }^{33}$

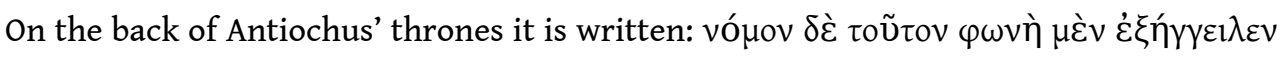

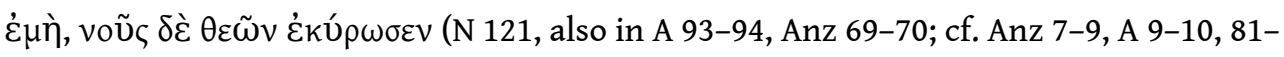

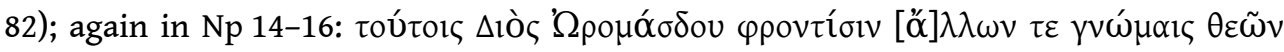

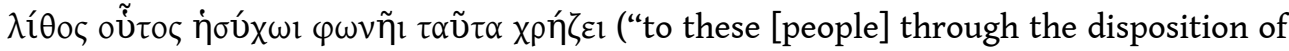
Zeus Oromasdes and the will of the other gods this stone announces following with silent voice"). The metaphor "silent voice" is probably too poetic for the Philadelphian stele, but the "silent voice" of the written text is evidenced by the silent act of touching

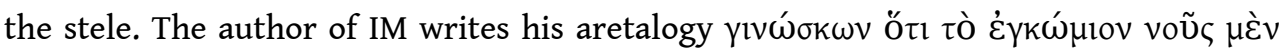

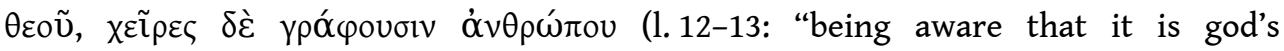
intelligence and men hands who write this praise"), and Aelius Aristides uses the same 
topos in his hymn to Serapis ( $\$ 16)$ and in his Hieroi logoi (2.2-4). In Hellenistic philosophical context the topos appears for instance in Aratus' hymn to Zeus (16-18).

\section{Information on the physical relation between the inscription and the cult foundation}

The importance of the relation between text and divine constructions and objects is most clearly seen in the funerary foundation of Artemidorus in Thera. The text is spread on the bases of the different altars and statues set up in the place following an elaborated iconographic and symbolic program. In Delos, though there is no indication of the place where the inscription must be erected, the purchase of land and the construction of a temple for Sarapis is the main subject of the text. Indications are given about the location of the temple. And even more important, Apollonius mentions right at the beginning of his text, that his grandfather brought from Egypt the statue of

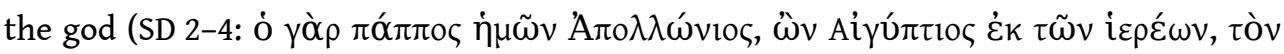

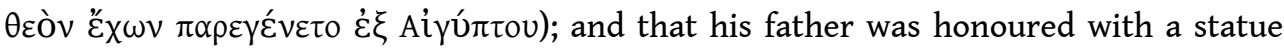
placed in the temple (1.10). ${ }^{34}$ In Antiochus' text Np the location of the stele is indicated immediately with its first reference in order to emphasize its divine content and the

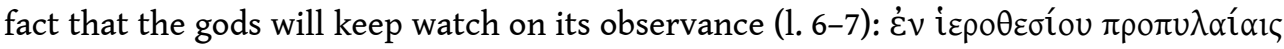
ódoĩ ("in the roads in front of the doors of the hierothesion"). The inscription $\mathrm{N}$ is related to the hierothesion built by Antiochus with the thrones of Zeus Oromasdes and the other gods set up on the top of the mountain (cf. the long description of the hierothesion and the thrones in N 24-67, and the description in A 57-66, Anz 20-32). In Philadelphia, it is only in the last part of the inscription where the location is

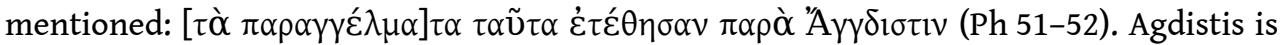
in fact the guardian goddess of the oikos and the one who promotes good thoughts in the participants, but the divine and forcing content of the statute is also emphasized through the enumeration, in the first part of the text, of all the altars (or images) set up in the oikos (1. 6-11). In Epikrates' testament the stele is said to be engraved with visible letters and put in the temenos in front of the grave, so that Epikrates' disposition is clear and does not get destroyed by the length of time, and so that no foreign can get into this property (EM 63-69).

In all texts intended to be publicly exposed and to inform the people, such as official decrees, reference to the location of the stele is usually made. In sacred informative texts, the way the information is given proves that indicating where the text must be exposed is not its first intention (it is in fact a private decision, and the location probably obvious). The main objective is to intensify the divine character and authority of the foundation or the regulations. The public and physical exposition of the text in relation to other material sacred elements is an effectiveness resource. In cult regulations and foundations the public exposition of the text has a clear informative character towards worshippers, but furthermore, it has a character of authority, and an aim of persuading the god. ${ }^{35}$ 


\section{Information about the god whom the foundation is dedicated to and about other gods who may be associated with the main one}

19 In almost all cult foundations, regulations, and also on rhetoric hymns, one or more gods appear together with the addressee. The nature of their relation expands from kinship to cult relation through mythic relation, similitude in the area of dominion or in the power or beneficiary acts towards mortals, or hierarchical relation. ${ }^{36}$

Artemidorus of Perge dedicates altars to the traditional Greek gods of the polis Zeus, Apollo and Poseidon, and to Hecate as protector of the agrarian hinterland; to gods that are individually worshipped: the Dioscuri, the mystery gods of Samothrakia and Priapus; and to the personifications Homonoia and Tyche. ${ }^{37}$ It is interesting to see that two of the three traditional gods in the temenos of Artemidorus are common to two of the three in Antiochus hierothesion: Zeus and Apollo, and moreover, that both are represented through the statues of an eagle and a lion. ${ }^{38}$

In Apollonius' account of the temple foundation in Delos, Isis is not forgotten as paredros of Sarapis in her role as wife, though she is only mentioned in the hymnic verse part (DAS 30-33), where even unnamed gods are invoked together with Sarapis and his wife as synnaoi in the final invocation (1.93-94). An indirect relation is also

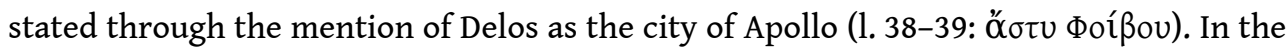
stele concerning the foundation of the cult to Sarapis in Opous, it is said that when Eurynomos is convinced of the veracity of Sarapis's command, he receives Sarapis and

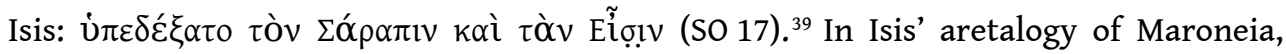
Sarapis is not omitted either (IM 15-20), and the goddess has further an important relation with Hermes, both as inventors of writing (IM 22, IK 3, etc); Isis and Sarapis are two gods, but they are invoked through many names (IM 19, HIs 1), most of them of clearly Greek tradition.

In Commagene, the divinized Antiochus shares cult with a syncretic group of gods that represents the Hellenic and Persian religious world of the king: Zeus Oromasdes, Apollon Mithras Helios and Artagnes Herakles Ares (N 54-56)..$^{40}$ But it is not only the religious world of the king. Zeus is the main Hellenic god, and Apollo is the ancestral god of the Seleucids, here significantly assimilated to Mithra and Helios. This is an early identification of Apollo with Helios that in Roman times will have its greatest success. ${ }^{41}$ Mithra is the Persian god of justice and law. No other gods are better invoked as overseer of sacred law and sacred place such as the one founded by Antiochus. Artagnes Heracles Ares represents the courage and heroism in war and in the defense of the king's territory, characteristics that Antiochus is in a veiled way attributing to himself in the text (N 64-66; cf. Np 1, 1.29-44 for proof that war was one of the main fears and risks in the reign of Antiochus and, as he expected, of his successors). ${ }^{42}$

In Philadelphia, Zeus transmitted the foundation statute to Dionysius, but Agdistis is the guardian goddess who watches for its observance and induces good thoughts to the worshippers, while Hestia and the Theoi Soteres have also images or altars, and so do the divine abstractions representing those benefactions granted by gods to mortals: [Eudai]monia, Ploutos, Arete, [Hygeia], Agathe Tyche, Agathos [Daimon], [Mne]me, Charitai and Nike. ${ }^{43}$ As in the case of Antiochus, Zeus is the better reflection of the Hellenic culture of Dionysius. Hestia is a proper paredros of Zeus for a private cult or 
sacred association. Of the divine abstractions of virtues, Eudaimonia (Happiness) represents a very important concept in Hellenistic philosophy; it is in fact one of the mercies that sovereigns and gods are expected to give their subjects and worshippers. Antiochus emphasizes in the praise to himself the value of eusebeia and hosiotes in order to have a blessed reign, a happy life, and the most pleasant joy for his subjects (N 1120). Plutus is one of the most expanded divine abstractions in Hellenistic times, and richness one of the most solicited gifts in prayers to gods. Artemidorus of Perge

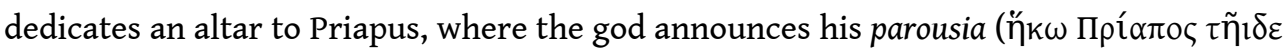

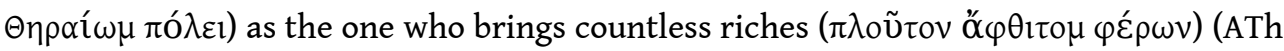

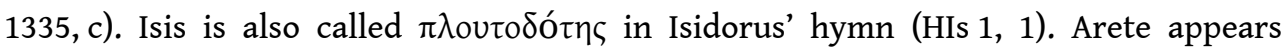
together with Sophrosyne in two altars from the sanctuary of Demeter in Pergamon (IvP II 310). Hygeia is, sometimes together with Ploutus or similar concepts, one of the main gifts attested in prayers or dedications. ${ }^{44}$ Agathe Tyche and Agathos Daimon are frequently attested as personal gods in Hellenistic times. Artemidorus sets the altar of Tyche as a way for his name to be remembered for eternity (ATh 1338); Antiochus' Tyche is mentioned always in relation to the gods he is worshipping (N 59-62, 74-5); the foundation of Posidonius in Halikarnassus (LSAM 72; SEG 15.637) is also consecrated to Agathos Daimon as protector of the founder and his wife, and to the Tyche Agathe as protector of his dead parents. ${ }^{45}$ Isis is called Tyche Agathe in HIs 1, 1. Mneme is an especial important value in foundations and funerary texts. Its presence in $\mathrm{Ph}$. is probably related to the intention of Dionysius to make a long living foundation and

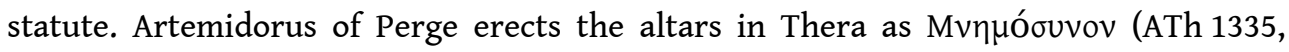
cf. 1338), and Antiochus lets the deeds of his goodwill (charis) be inscribed forever ( $\varepsilon i \varsigma$ xpóvov aíwviov, N 9-10). This virtue is also related to the importance of the written word in these texts and to the desire of the founder to live eternally through his foundation (cf.supra). ${ }^{46}$ To the Charites is dedicated another image or altar in Dionysius' oikos. The importance of charis as divine benefaction towards mortals is well

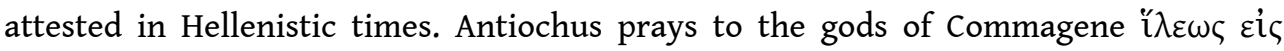

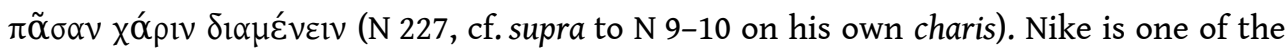
main achievements of the gods in Hellenistic and Imperial aretalogies. Sarapis achieves the victory for Apollonius in Delos (SD 27, cf. 85-94), and Isis is also a victorious goddess (IK § 55). Many of these gods are also soteres (see $\$ 10$ on acclamations).

The appearance of other gods in relation to the god who has ordered or who is object of the foundation in these texts has some characteristics that are particular to the new religious mentality. Traditional Greek gods cannot be missing if the foundation is dedicated to a public community. The main reason for this is the mixed culture of the author and the combination of tradition and innovation. The oriental culture is reflected through a strong presence of "oriental" gods (Isis, Serapis, Agdistis, Samothrakian gods) ${ }^{47}$ Besides, there is a strong presence of new Greek divine beings: divine abstractions (Tyche, Homonoia; the abstractions of Philadelphia; Agathos Daimon, the tyche of Antiochus; cf. the agathos daimon of Posidonius' ancestors in Halikarnassus) that were gaining great popularity in Hellenistic times as personal and local gods who can give individuals and members of a community all they are seeking for. ${ }^{48}$ The new henotheistic character of some divinities is also "inconsistently" emphasized through their relation to other gods. ${ }^{49}$ In the hymns of Aelius Aristides the addressee god is usually the henotheistic supreme god, whose powers are delegated and transmitted through other divine beings as in the hymn of Zeus (HZeus 25-27).50 
In sacred norms, accumulation of divine beings often appears in imprecations directed to transgressors. The efficacy of imprecations was probably thought to be stronger if they were put under the surveillance of many gods. A good rhetoric funerary example is the inscription of Neocaesarea (Strubbe [1997], no. 155).

The different divine strata accomplish the objective of representing the different cultures of the founder, protecting the foundation and chastising the transgressors, and awarding all wished goods to the worshippers. In some cases, the presence of different gods emphasizes the henotheistic character of the main god as it happens in the aretalogies, whether they are related to a foundation or not.

\section{Tradition and innovation in cult foundations and regulations}

The different strata of divine beings are in consonance with the founders' belonging to a syncretic greco-oriental culture. While new religious elements and mentality is pervasive throughout the foundation texts, the authors are very interested in making the traditional elements explicit. Regarding his grandfather, Apollonius says:

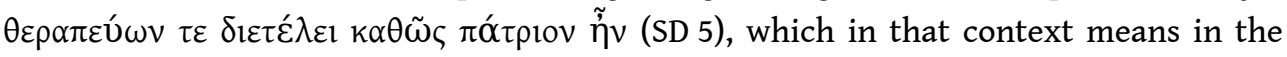
Greco-Egyptian way. In Commagene, the images of the gods are made following the tradition of Greeks and Persians; the Persian, Macedonian and Commagenian gods are called patrioi in N 224; feasts and sacrifices are established following the ancient way

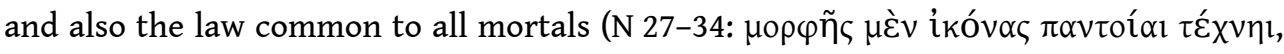

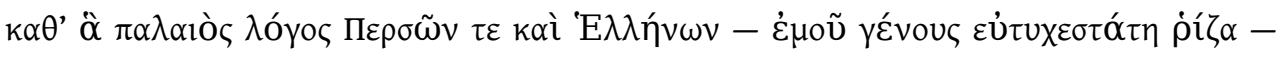

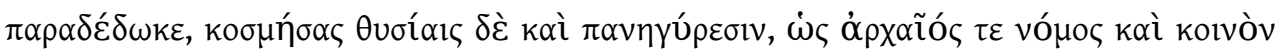

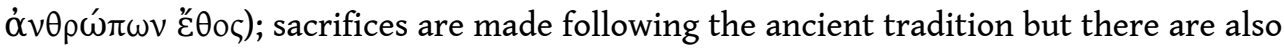

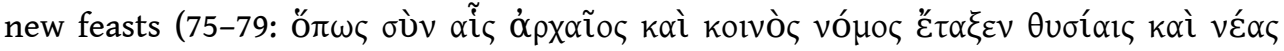
غ̇optò ৎ [...]; cf.A 11-140). In Philadelphia the sacral ceremonies are to be done

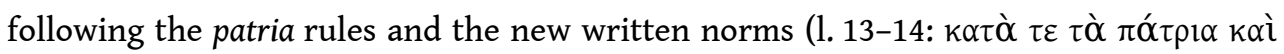
$\dot{\omega} \varsigma v \tilde{v} v[\gamma \varepsilon ́ \gamma \rho \alpha \pi \tau \alpha 1])^{51}$

The explicit reference to the respect of ancient traditions as divine obligation is also a topos in rhetoric hymns. What is divine is patrios, and what is divine men shall not change. This last idea is well expressed in the hymns of Isis: $\dot{\varepsilon} \gamma \grave{\omega}$ vó

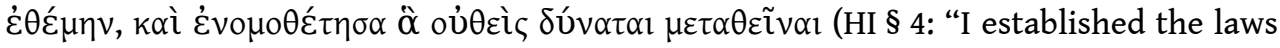
for humans and legislated what no one can change"). The location of a sacred stele in relation to an ancient cult place is also stated in some hymns as means of authority. In

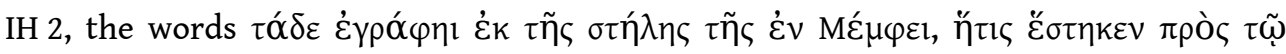
'H temple of Hephaistos") emphasize the ancient tradition and Egyptian origin of the aretalogy as a source of authority. Following this same purpose is the reference of Egypt as the place to live that was chosen by Isis in the aretalogy of Maroneia, and of Eleusis as a place to reveal her euergesia (IM 34-41). The importance of the reference to the temple and sacred objects in sacred texts is clear for instance in Aristides Hieroi Logoi, where the author very often mentions sacred spaces and objects in order to emphasize the protection he receives from the god. In 1.1, for instance, he mentions the statues of Agathe Tyche and Agathos Daimon inside Asclepius' sanctuary in 
Pergamon, and also his concern when he realizes that the statue of the god is new, and asks for the old one in order to prostrate himself to its feet. ${ }^{52}$

This topos together with the mixture of divine strata is a good reflection of religion in Hellenistic and Roman times. There is no break with traditional religion; the great Hellenic gods and the cult of the polis continue being a pillar of religious life. But new gods appear, especially Greek divine abstractions of virtues and oriental or syncretistic divinities with elements that do not belong to traditional Greek religious conceptions, but fit in the development of Greek religion and philosophy.

\section{Information concerning worshippers for whom the foundation is erected}

One of the aspects that has awaken more interest in Dionysius' foundation in Philadelphia is the three times mentioned access of men, women, free persons and slaves to the oikos (Ph 5-6, 15-16, 53-54). ${ }^{53}$ It has been compared to Christian mentality, but the fact that slaves and women were also accepted is not so rare in Greco-Roman associations or private cults. ${ }^{54}$ What is more striking, and probably demonstrates an especial religious or philosophical rhetoric, is the insistence on the assertion. The universality of humankind and the equality of sex, race and social status is one of the main themes in stoic sources, as is well known. It starts being a subject in the new religious discourse since the $3^{\text {rd }}$ century $B C$. In the altar dedicated to Priapus,

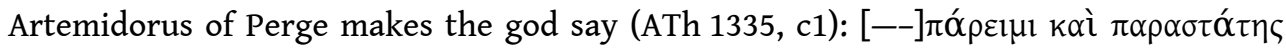

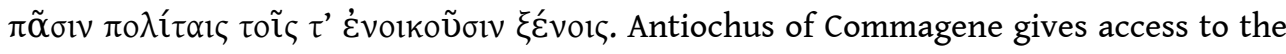
sacral commemoration to citizens and foreigners, kings, dynasts, free persons, slaves and all those who differing in race-name and in life condition share a common human

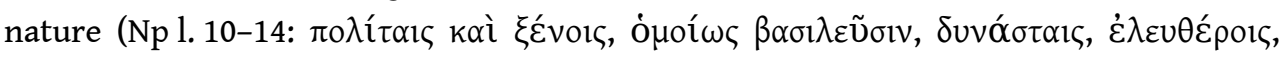

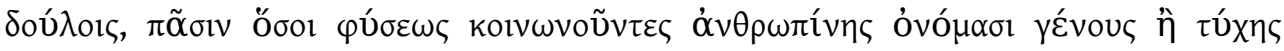
$\delta ı \alpha \varphi \varepsilon ́ p o v \sigma l v)$. Epikrates from Magnesia designates as heirs of his funerary foundation two of his freedmen, one after another and, after the second one, his succession line masculine as well as feminine (EM 1. 52-8). ${ }^{55}$

This emphasis on the universal and philanthropic power of a god and on a common human nature also underlies following words in the aretalogy of Maroneia (1.24-26):

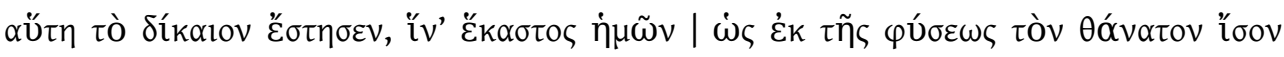

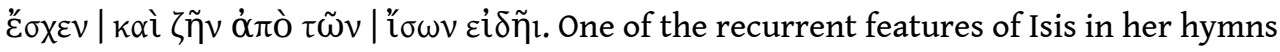
is that she invented language for Greeks and Barbarians as well (HI: $\S 31 \dot{\varepsilon} \gamma \grave{\omega}$

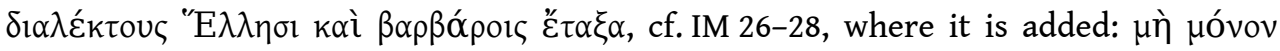

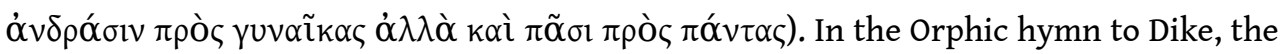
goddess is presented $\kappa \alpha \theta 0 \rho \tilde{\omega} \sigma \alpha \beta$ ßíov $\theta v \eta \tau \tilde{\omega} v \pi \circ \lambda v \varphi v \dot{\lambda} \omega \omega$.

31 This reference to all humans as members of a universal and common world does not imply that all persons have the same rights and functions in life. Even when it is said in the NT that "in Christ there is no slave, no free person, no Jew, no Greek, no man, no woman" (Col.3.9-11; Eph. 4.22-24; Gal 3. 27f.), it does not mean that there was no difference between men and women, slaves and free persons in the real life of Christian communities ${ }^{56}$ In the long hieros nomos of Commagene, where everybody had access, there are precepts referring to sacred slaves (N 171-191; cf. A 141-164; Anz 111-123) that were to be well treated and not used as private slaves by any other king or dynast, 
but that were designed by Antiochus as sacred slaves with sacred duties and could not escape that status, neither their descendents could. The access in Philadelphia to the different strata and sex does not mean that they were all equal, and evidence of the differences is the fact that the sexual precept is different for free women and slavewomen, and also different for men and women. Like in other mystery cults, the lex sacra from Andania (LSCG 65) was written for men, women, free men and slaves, but they differed in the oaths they had to swear, and in formal aspects like the way they had to dress in the cult ceremonies. What is important and particular in the texts of Philadelphia and Commagene is the acceptance of a common religious world where different cultures and social strata are integrated.

\section{Topoi concerning the content of the foundations' norms: morality, justice, philanthropy}

Though the sacred foundations may be very different in their nature and in the character of their dispositions and regulations, there are some elements in their content that seem to be the subject from the $3^{\text {rd }}$ century and mainly from the $1^{\text {st }}$ century $\mathrm{BC}$ onwards. People accessing the sacred foundation are asked to have a behaviour that goes beyond the normal ritual norms from earlier times, or that are only isolated and modestly expressed in some earlier cult regulations.

The necessity of being honest in mind for pleasing the gods is clearly expressed in the

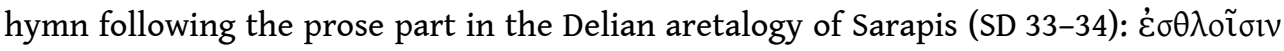

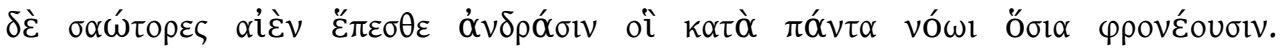
Furthermore, the deceitful deeds of some people are punished by the god, though in

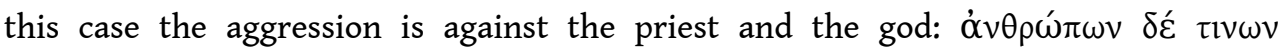

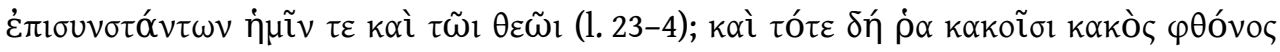
$\varepsilon \check{\varepsilon} \beta \alpha \lambda \varepsilon$ (l.66), and cf. the lines 81-90, where the god is the winner in the trial concerning the purchase of the land to build the temple. The first clause in Np (1. 17-24, = A 199-207, Anz 151-160) says that if somebody intends to get into the sacred place conducted by blind ignorance, without the sanctity of righteous acts not sacred with

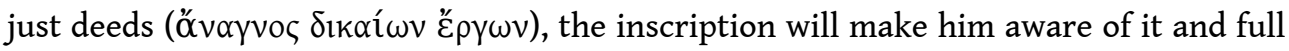
of fear he will go away to another place and get purified of his sin. In N 11-23 Antiochus makes his own praise relating benefaction towards mortals with piety towards gods. He says that he escaped big perils because he knew that eusebeia is the best virtue and because hosiotes was the guardianship of his whole reign. ${ }^{57}$ The general idea of just behaviour between mortals is inherent to the whole Philadelphian regulation: not to use deceit ( $\delta$ ó $\lambda_{01}$ ) against other people and, in a general way, not refraining oneself of having good intentions towards the oikos; a man shall not commit adultery with any married woman, and no other person shall be accomplice or know about it without making it public; a free woman shall not have intercourse with any man except her

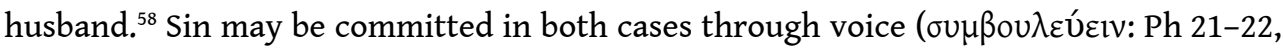

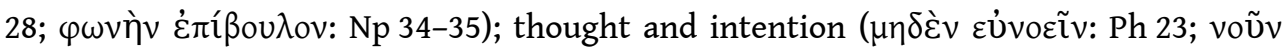

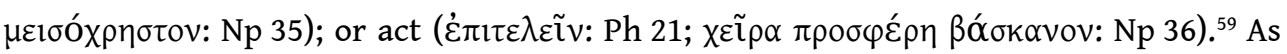

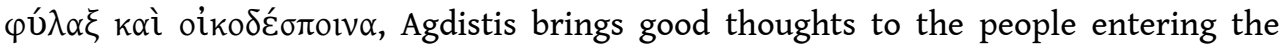
oikos. Purity of thought lies beneath the tactic used by Dionysius in order to guarantee the observance of the regulations. The necessity of having good thoughts or being pure not only in the body but also in the soul in order to enter a sacred place begins to 
appear in Hellenistic times, though most of them belong to the Roman period. ${ }^{60}$ Most of these cases come from Asia Minor or are related to oriental divinities.

Prayers to the gods so that they create good thoughts and behavior in humans are not common in Hellenistic sacred norms, but in a general way the idea is insistently expressed in aretalogies to Isis. In IM 29-30 the goddess is praised for having instituted law instead of violence in the cities, and made children honour their parents; and because she turned the necessity of Nature into Law. The idea of justice is especially

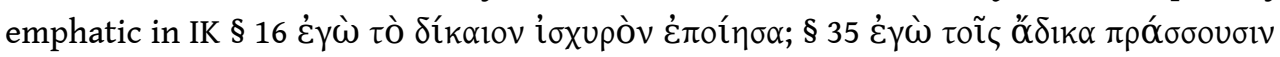

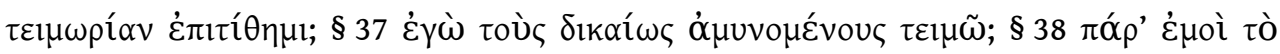

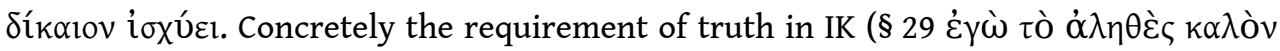

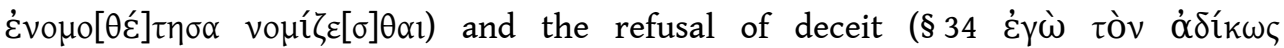

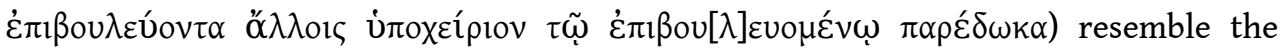
content of Philadelphian norms. ${ }^{61}$ The same conception appears later in some Orphic hymns, where law as guarantor of justice is also praised (Orph. H. 64 to Nomos: law as companion of most honest thoughts), or where gods inspire good thought and moral

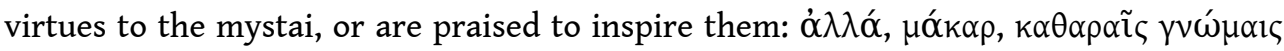

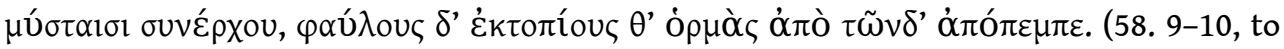

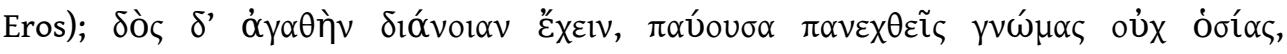

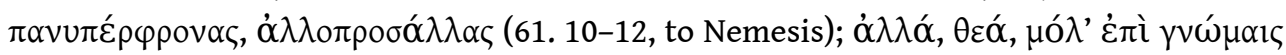

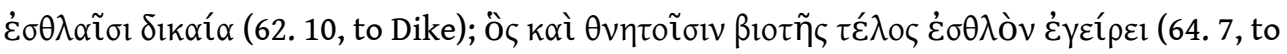
Nomos). Cf. 63. 12-14, to Dikaiosyne. It is probably not casual that the concept of justice, law and honest thoughts pervades the whole corpus of Orphic hymns that are supposed to originate in West Asia Minor, maybe in the area of Pergamon and Lydia, an area where, together with the bordering Phrygia, this moral requirement is strongly interwoven with religion. ${ }^{62}$ The importance of justice in the religious texts is especially attested in Phrygia, but also in border regions, where not casually a god Hosios kai Dikaios (representing the same relation between justice and piety that we find in Antiochus' inscription) was especially worshipped..$^{63}$ The Orphic hymn 62 to Dike (cf. also 61 to Nemesis, 6-12) is a very good parallel for the justice imposed to Dionysius' oikos, where Agdistis will promote good thoughts to the people that have access to it, but where divine punishment will strike over all those who transgress the norms.

Nomos, which does not appear in traditional hymns and other religious texts, becomes a central concept in sacred texts during Hellenistic-Roman times. Eusebeia and hosiotes are traditional religious concepts that become now related to justice. Eusebeia towards gods is the way to achieve justice, as we can see in Antiochus' text. Gods become incarnations of piety and justice (the best example is the god Hosios kai Dikaios) and are praised to award mortals these virtues. The way to be pious and just is to follow the law, which is imposed by the gods (cf. supra $\$ 2$ ). Virtues required from worshippers are the same virtues for which gods and sovereigns are praised. All of them are manifestations of philanthropy. In his treatise on how to praise emperors, Menander mentions the qualities of knowledge and temperance, but he actually stresses justice and legislative capacity (2.375). 


\section{Elements to force the observance of the norms: oath, imprecation and public confession}

\section{Oath}

Just as in civil laws and decrees, information about the obligation to respect the norms is always included in foundation statutes and cult regulations. And in the same way as in civil norms, the elements to guarantee the respect of the norms are obligation of oath, threat of fine and threat of divine chastisement, i.e. imprecation. Dionysius' statute is presented as the example of an oath to be swore by all those who went into the sacred place (or who became members of the association). People entering the cult place or association had to make an oath declaring that they will observe the regulations, but their behaviour will be tested regularly through a peculiar ritual. Members who consider themselves pure and obedient of the regulations will demonstrate publicly that they are observers of the precepts. They will do it by touching the stele where the regulations are written on the occasion of the monthly and yearly rituals. Members who are not observers will refrain from touching the stele. The effectiveness of Dionysius' ritual lies in the Greek and oriental idea of perjury as one of the most offensive and impure sins against the divinity. Perjury is in fact the most frequent sin attested in the Anatolian confessions (cf. BI 2, 15, 27, 34, 52, 53, 54, 58, 110 [indirect], 120). ${ }^{64}$ The importance of the oath in these examples reminds us of Isis'

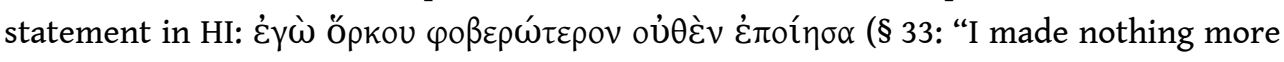
frightening than oath"). ${ }^{65}$

\section{Imprecation}

Much more important than oaths as elements in foundation texts of this time are the imprecations. Imprecations are very well known in the Greek world in civil and religious texts. In the inscriptions dealt with in here, the divine power of chastisement plays a very important role, and the expected high degree of effect is probably related to the intensity of imprecations, though rhetoric plays not a minor role. The force of

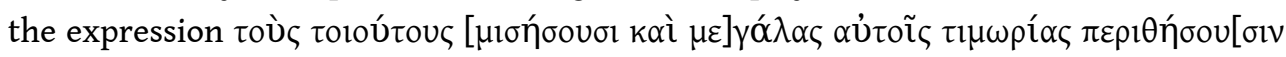
(Ph 49-50: "such people they hate and bring on great punishments") is, though much

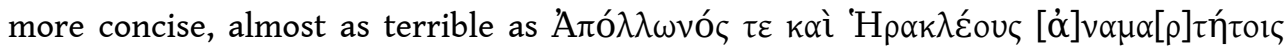

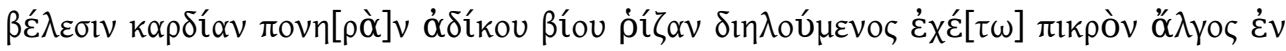

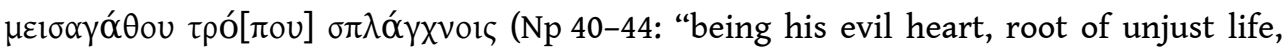
pierced through by the arrows of Apollon and Heracles, he shall feel bitter pain in his inner being that hates all what is good"; cf. also N 105-122, 205-211 and A 220-228: "such person shall expect harsh state of mind from all gods, for implacable Penalties, servants of the gods' great rage, persecute criminal life with all sort of punishments until they complete justice. He shall know that heavenly law drives the gods' heavy hands with immortal determination to the punishment of bad persons. Through these hands shall the impious behaviour pay the owed justice to the implacable rage." 66 In the testament of Epikrates in Magnesia the imprecation for those who transgress his

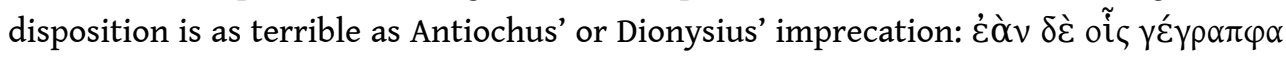

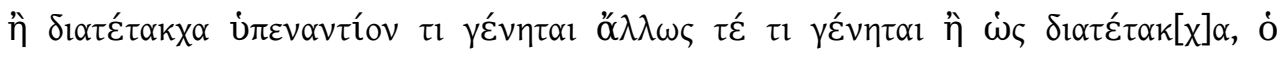

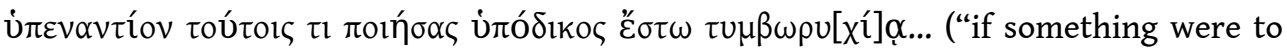


happen opposite to what I have written down or arranged, or if something were to happen in a different way from what I have arranged, whoever acts in opposition to this, let him be liable as a grave robber") followed by all sort of harmful wishes, and

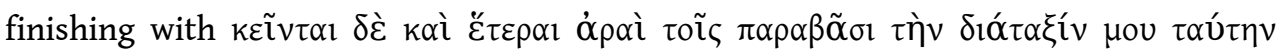

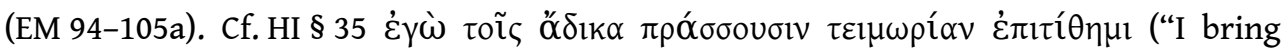
punishment to those who do unjust things"). Accounts pertaining to the chastisements of gods give us an idea of what people asked for and feared through imprecations. The punishment Sarapis inflicts to the transgressors in SD (1.85-90: they were bound fast, their tongues turned mute, and became like god-struck images or stones) is similar to the punishments desired in the well known judicial defixiones; and through the Anatolian confessions (see infra) we find all sort of illnesses and even death of the transgressor or a related person as divine revenge. The strong elaborated imprecations that we find in some of these texts have surely a rhetoric function, but they are based on religious feelings and conceptions that are especially strong in oriental cultures. ${ }^{67}$

The efficacy and force of imprecations is achieved not only through terrible threats directed to transgressors, but also by means of stressing the power of the god, and this is mainly done through rhetoric acclamations where the god's name and epithets, as well as his area of influence, are emphasized. ${ }^{68}$ Acclamation is a feature that imprecations have in common with aretalogies or prayers (cf. infra).

Both imprecations after the second clause in $\mathrm{Np}$ and $\mathrm{Ph}$ are based on this sort of

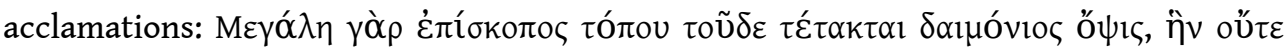

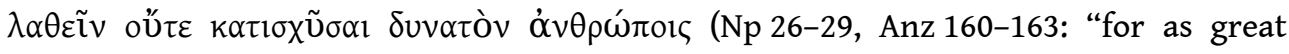
overseer of this place a divine sight is located, that men are not able to escape or

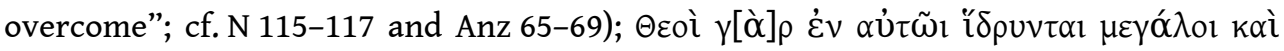

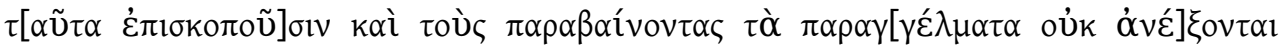
(Ph 31-35). ${ }^{69}$ The effectiveness of imprecations is due to the absolute confidence on the fact that the gods can examine everything and see who transgresses the norm. In confession texts and in prayers for justice the gods also look out for the sinners

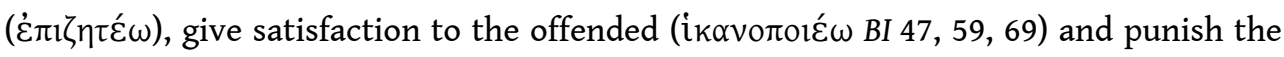

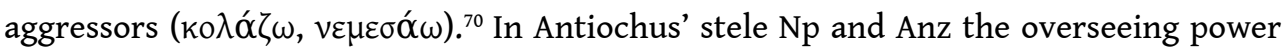

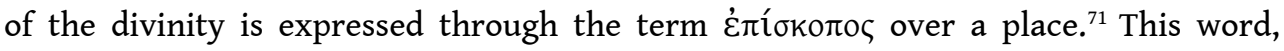
common in Classical and Hellenistic decrees for overseers of finances or other public inspectors, is expanded to encompass similar positions in private associations. It is very common in LXX and NT for religious officials, but it is not usually attributed to the god.

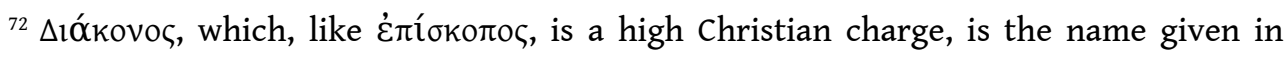

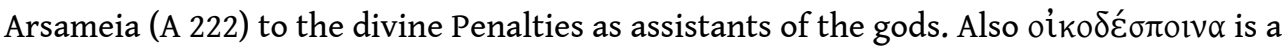

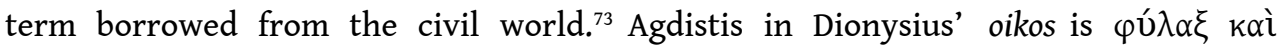

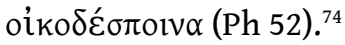

\section{Public confession}

Evidence for the efficiency of the belief and advertising of divine chastisement can be found in the so-called confessions. The importance of the moral behaviour of men and the philanthropic attitude of gods is emphasized by the new trend of making it public. In the case of the worshippers this has surely an exemplary function, same as in civil honorific decrees. In relation to this new emphasis on the general moral aspect of thought and behavior of the worshippers, public demonstration of their pure or impure 
state is an important feature in Dionysius' statute, where people publicly confess, through the touching of the stele, their pure state, and where people are required to make public the sins of others. The ritual of making public who transgresses the norm and who does not in Dionysius' oikos has surely an exemplary function, such as the one we find in the public confessions of Lydia and Phrygia. Dating from the first to the third centuries $\mathrm{AD}$, these inscriptions narrate the infractions committed by common people and describe the punishment that the divinity has inflicted upon them and how they have been saved and forgiven. ${ }^{75}$ The public confession is in fact directly related to the public exposure of the divine powers, which becomes a topos.

The public character of worship is especially evidenced in praises and aretalogies to oriental gods in late Hellenistic and Roman times, especially to Isis and Sarapis. Already the Delian aretalogy says: "when the moment of the trial came, the whole city and all mixed tribes of foreigners gathered together at the temple to listen to the divine wise

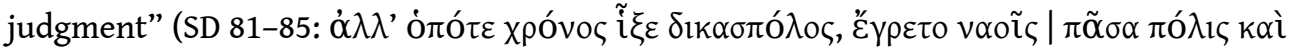

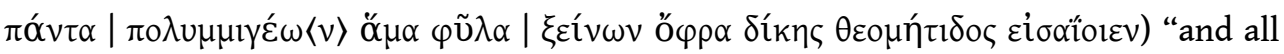

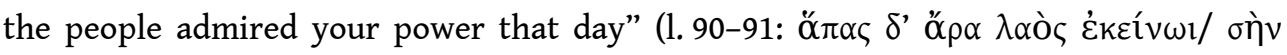

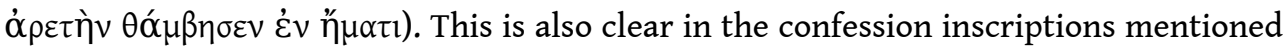
above, where the offender can only free himself from punishment and obtain forgiveness by writing down the events on a stele and thus demonstrating the enormous power of the god. The public exposition of Asclepius' cures is another example of this necessity of making divine propaganda, which is also well attested in the sacred discourses of Aristides, where he often mentions the miraculous cures by Asclepius in his friends' presence (e.g. 2.51). ${ }^{76}$

\section{Acclamations}

41 As we have seen, acclamations play an important role in imprecations. The main elements of the acclamations are the divine names and the epicleseis. The topos $\dot{\alpha} \pi \grave{o}$

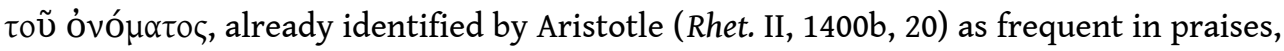
is very important in hymns. ${ }^{77}$ But they are also an important element in other sacred texts. Though they are to be found all through religious texts, they are especially common and important in invocations, at the beginning and end of the texts, and in imprecations and prayers. In the texts we are concerned with, I would highlight two types of epitheta: those denoting the magnitude or extension of the divine power, and those denoting the beneficial attributes of gods towards mortals. We have already seen examples of the first type in the imprecations. The terminology used for denoting divine supervision is also related to the oriental conception of divinity as lord of a

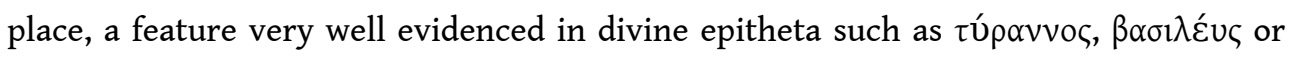

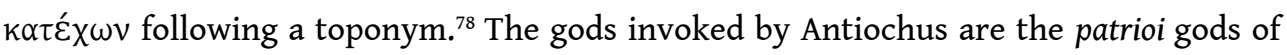
Commagene.

Divine power is also an important issue in acclamations inserted in aretalogies. Isis is

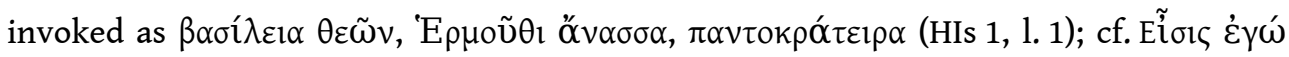

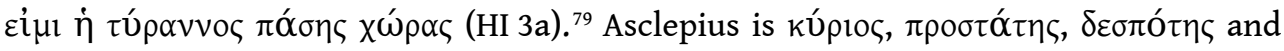

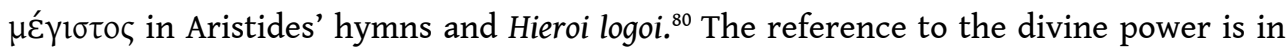
this way condensed in the god's name and epicleseis.

For the same reason that divine abstractions are so common from Hellenistic times onwards (cf. supra), epicleseis denoting divine philanthropia are also frequent. In the 
statute of Philadelphia, Zeus is called eumenes (1.6-7). ${ }^{81}$ Eumenes (propitious, benevolent) is the concern with which the gods have often looked upon Antiochus by

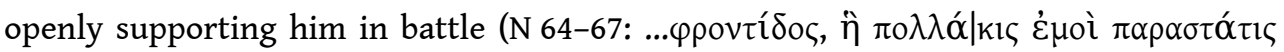

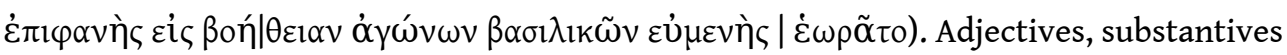
or verbs with this root are also very common in relation to different gods in the Orphic hymns, in most cases as an expression by the initiated of the desire that the praised god

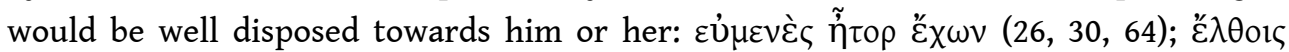

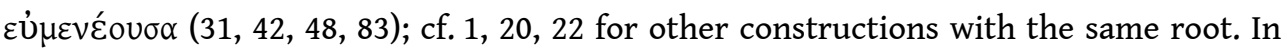
the hymn dedicated to Sarapis by Aristides, the god is said to be eumenes towards men

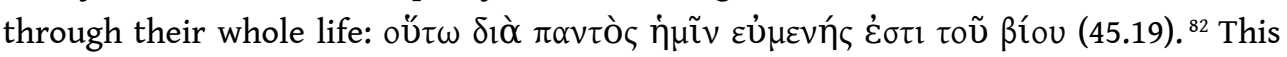
sense fits Dionysius' text very well and fits the theoi soteres and the long series of divine abstractions of virtues and benefits that follows.

At the final prayer of the statute (1.60), a god whose name is not preserved, probably Zeus, is called Soter again. Also soteres are the Dioscuri whom Artemidorus dedicates

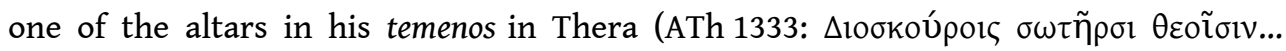

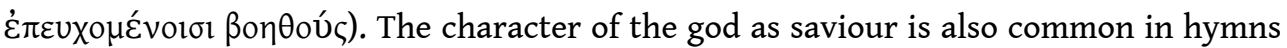

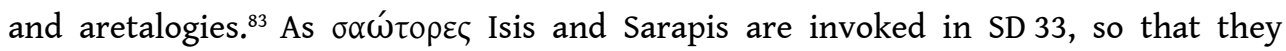
protect good people who have pious thoughts. Related to this sort of epitheta are

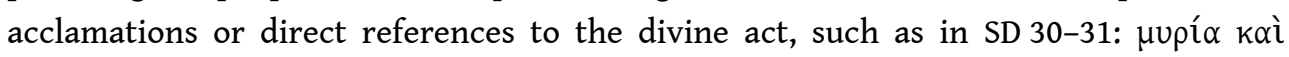

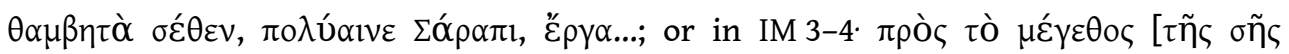

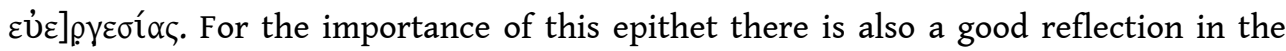
dice and alphabetic oracles of Imperial times in Asia Minor, that express really well the main concerns of the people. On the dice oracle of Cremna (I.Central Pisidia 5), Zeus (17), Tyche (19), Isis (25) and Hermes (26) are soteres. This oracle is in fact a very good example of the combination of traditional gods, new personal oriental gods and divine abstractions.

An especially significant type of epiclesis in this time is the one expressing the polyonymia of the god, for it is a reflection of his henotheistic character, the summit of

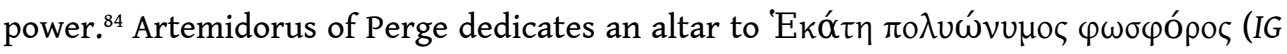
XII 3, 421). Hecate appears often identified with Artemis, Core and Selene. The henotheistic character of the term polyonymos is here intensified by the epithet phosphoros. This epiclesis, though apparently a functional symbol showing the goddess through a torch that brings light, becomes very common from Hellenistic times onwards as attribute of the mentioned goddesses. As Zografou says, light is a symbol of the divine apparition (parousia), and parousia means soteria. ${ }^{85}$ The epithet phosphoros is also attested in relation to other henotheistic gods, especially Men (ICentral Pisidia 5.51) or Helius (5.42). Again some of the best examples of polyonymia are in hymns and aretalogies to Isis, as for instance the first hymn of Isidorus: $\sigma \omega \dot{\omega \varepsilon 1 \rho ' ~} \dot{\alpha} \theta \alpha v \alpha$ $\tau \eta$, $\pi \circ \lambda v \omega \dot{v} v \mu \varepsilon$, 'I $\sigma 1 \mu \varepsilon \gamma i ́ \sigma \tau \eta$ (HIs 26, cf. 14-24, esp. 23f., where the names of many different goddesses are attributed to her). In the Isis' aretalogy from Maroneia it is said to Isis and Sarapis: "you are two but you are invoked in many ways among mortals" (IM 1920). ${ }^{86}$

The importance of the name is expressed also through invocations such as

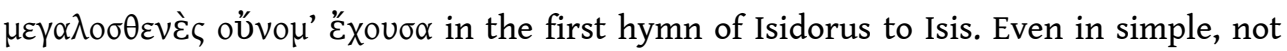
rhetorical inscriptions in Asia Minor, the importance of the name is stressed in

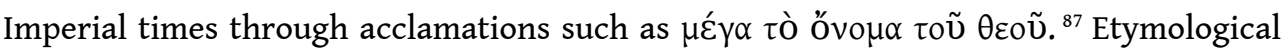
wordplay with the names of the gods, common in hymns, intensifies also the value of 
the name. In the Isis aretalogy of Maroneia, there is wordplay between the adjective loos and the name of the goddess (IM 24-26). ${ }^{88}$ Following Aristides, knowing and understanding the name of Zeus is the way to know his greatness. ${ }^{89}$

\section{Prayer}

Prayer is a common element to all sacred texts. Requests to the gods appear usually at the end of hymns, foundation texts, cult regulations, and many votive inscriptions. This traditional place for prayers continues being a preferred place in the Orphic hymns, Aristides' hymns, and Isis aretalogies. But they may also be included in other parts of religious texts. The request in the hymnic composition to get inspiration, which is a topos in traditional poetic hymns as a final prayer, is also a topos in rhetoric hymns, although they do not necessarily appear at the end..$^{90}$ As an extension of the same topos, the god may inspire intelligence and good composition not only for hymnic composition, but in general. This element is especially frequent in Aristides' hymns, where he prays to the god to help him compose good discourses. ${ }^{91}$ As a variation from this subject, there is a new topos concerning the "inspiring" god in Hellenistic and Roman times. The god can also inspire good thoughts and behavior in the worshippers. Though not expressed as request to the goddess, we have already seen that Agdistis has this function in Dionysius' foundation in Philadelphia. ${ }^{92}$

But prayers in sacred foundations and regulations are, like in civil laws and decrees, especially related to the imprecation, and they concern all people whom the regulations are addressed to as stated in the text. The prayer is, like the imprecation, of a general character, wishing those who respect the norms all sort of good fortunes. Same as in imprecations, prayers make use of acclamations with divine epicleseis and references to the power of the god in order to make the god better disposed to attend men's wishes. In his treatise, Menander (2.445.25-446) says that there is a direct relation between the effectiveness of the epiclesis and the results of the prayer. ${ }^{93}$

Antiochus of Commagene prays to all patroioi gods of Persia, Macedonia and Commagene to be propitious to those who respect the norms (N 223-234). The prayer gains force through the mention of the area under the power of the gods. Dionysius of Philadelphia prays to [Zeus] with the epithet soter in order to achieve health, salvation, peace, and safe passage through land and sea ( $\mathrm{Ph} \mathrm{62-64).} \mathrm{Though} \mathrm{it} \mathrm{is} \mathrm{not} \mathrm{explicitly} \mathrm{a}$ prayer, it is said that members who are consequent with the regulations will get the goodwill of the gods and all good things, both physical and material, that gods give to the people they love (1. 46-48), and that are represented by the divine personifications whose altars or hiera sacra are established in the oikos and for whom the initial oath must be made: Happiness, Wealth, Virtue, Health, Fortune, Good spirit, Memory, Grace, Victory. ${ }^{94}$ As Weinreich already stated, six of the divine personifications in Dionysius' stele appear as addressers of Orphic hymns that are supposed to be composed for a mystery group..$^{95}$ In the first hymn of Isidorus to Isis, when prayed to be propitious and

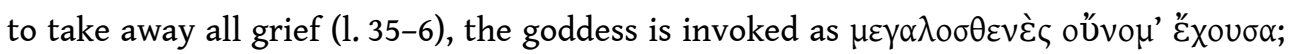
in the second hymn, when prayed for getting richness and offspring (1.29-30), she is

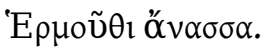




\section{Conclusions} to Hellenistic philosophy, especially by Weinreich. ${ }^{96}$ These ideas correspond precisely to features of the oriental religions that the Greeks were getting in contact with. Moral and behavioural attitudes that in the Greek world belong to philosophy are aspects of religion and are judged by the gods. This is very clear to see not only in the new Christian religion, whose communities are for this reason frequently compared with philosophical schools, but also in the evidences of indigenous gods of Asia Minor or in the cult of Isis. On the other hand, Hellenistic philosophy was very much influenced by oriental mentality and religious concepts. The widely spread Stoicism had much in common with oriental religion, especially in the conception of a superior divine power and the importance of ethics and morality in relation to religion.

51

Very good antecedents to later hymns are in fact the early third century BC stoic hymns of Cleanthes and Aratus. ${ }^{97}$ In Cleanthes' hymn to Zeus, the god is first invoked as

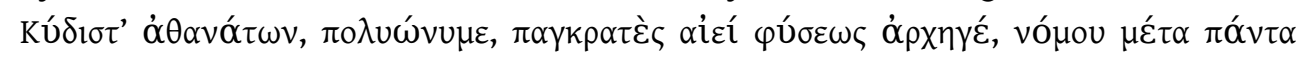
$\kappa \nu \beta \varepsilon \rho \nu \tilde{\omega} v$. Already in these two verses the god is presented with the same epiclesis we have seen in the texts analysed here that stress the god's power, his henotheism and the importance of law. The central part of the hymn is not dedicated to celebrate the mythical history of the god, but his beneficiary acts towards mortals. The opposition between good and evil and the presentation of the divine being as a fighter against evil and the enforcer of the universal law recalls the texts we have analysed, especially Isis' aretalogies. Knowledge and good thought are also here a clue to lead a virtuous life. The idea of a universal law is presented again as the final part of the hymn, where Cleanthes estates that it is necessary for mortals, as compensation for the divine acts, koเvòv ơ law").

Aratus' invocation to Zeus (Phaenomena, 1-18) is a presentation of Zeus as civilizing god; as Isis in her hymns and aretalogies, he has created everything and taught mortals all they need to lead a proper and civilized life.

The idea of universality and a common world for everyone that impregnates Cleanthes and Aratus hymns to Zeus is even clearer in philosophers of Imperial times, stoics and epicureans such as Marcus Aurelius and Diogenes of Oinoanda. In Diogenes' long epicurean inscription we find the same ideas we have seen in the texts analysed here: the importance of good thought (cf. SD, N, Ph); the idea that what is in accordance to nature is the same for everybody (cf. IM); philanthropy towards foreigners (SD, N, cf. $\mathrm{Ph}$ ). The opposition between good and evil is presented by Diogenes as an opposition between health and illness. Through his philosophical text, he pretends to heal the world's epidemic in order to spread happiness, in the same way as Antiochus says that he has achieved happiness in his reign through his eusebeia. Diogenes says explicitly that he wants to achieve his purpose using the wall of the porticus so that he can expose publicly the remedies for salvation. Public exposure, reference to the physical presentation of the text, soteria for the whole world through good thoughts and knowledge, those are all elements that belong to this new religious discourse.

There are of course many elements that are features only of the aretalogies of Isis and Sarapis, or only of sacred foundations in the Eastern Mediterranean, or only of Antiochus' sacred foundation, or only of Minor-Asiatic ex-votos. The Delian aretalogy 
of Sarapis has been interpreted through Egyptian religious customs and traditions, and so has Antiochus' texts through Persian culture ${ }^{98}$ There are without a doubt many particular local elements that explain many features of these texts; but there are many others that have been interpreted as products of Egyptian, Persian, Christian or Anatolian influence that are nevertheless common to the whole East Mediterranean and that should probably be interpreted as a Hellenized common oriental stratum, i.e. as the Greek selection of oriental features that shapes a new religious discourse.

The education and literary aim of the authors of SD, N, Np, A, Anz, Ph, IM and of verse hymns to Isis is revealed not only by formal features, but also by the fact that they are developing a religious discourse that incorporates the new features of Greco-Roman religion, strongly influenced by oriental religions, at the same time that they are well aware of the new philosophical trends that were very much pervaded with religion at this time. Aelius Aristides' corpus of prose hymns and sacred speeches, and the collection of Orphic hymns already have a long rhetoric tradition available that fits the religious mentality of Imperial times, and that is not exclusive to hymns.

\section{Abbreviations of the analysed texts}

\begin{tabular}{|c|c|}
\hline A: & $\begin{array}{l}\text { Antiochus' inscription in Arsameia on the Nymphaios (IGLSyr 1, 47; DöRNER, in DÖRNER - GOELL [1963], p. 40-59; } \\
\text { WALDMANN [1973], p. 82-89, with German translation, p. 90-96); } 1^{\text {st }} \text { cent. BC. }\end{array}$ \\
\hline Anz: & $\begin{array}{l}\text { Antiochus' inscription in the temenos of Ancoz (reconstruction of the text established by WAGNER - PETZL [2003], } \\
\text { p. 91-96); } 1^{\text {st }} \text { cent. BC }\end{array}$ \\
\hline ATh: & funerary foundation of Artemidorus from Perge (IG XII 3, 421f., Suppl. 1333-1348); Thera, $3^{\text {rd }}$ cent. BC. \\
\hline EM: & Epikrates' foundation in Magnesia of the Sipylus (HERRMANN - POLATKAN [1969]; MALAY [1994], no. 20); $2^{\text {nd }}$ cent. AD. \\
\hline HIs: & Hymns of Isidoros to Isis (SEG 8.548-551; VANDERLIP [1972]; тОTTI [1985], no. 21-24); $1^{\text {st }}$ cent. BC. \\
\hline IK: & Isis aretalogy from Kyme (IK Kyme 41 ; тоттI [1985], no. 1$) ; 1^{\text {st }} / 2^{\text {nd }}$ cent. AD. \\
\hline IM: & Isis aretalogy from Maroneia (GRANDJEAN [1975]; тоTTI [1985], no. 19$) ; 2^{\text {nd }} / 1^{\text {st }}$ cent. BC. \\
\hline $\mathrm{N}:$ & $\begin{array}{l}\text { Antiochus' inscription on the back of the thrones in his hierothesion in Nemrud Dagi (OGIS 383; IGLSyr 1, 1; } \\
\text { WALDMANN [1973], p. 62-69, with German translation in p. 71-76); } 1^{\text {st }} \text { cent. BC. }\end{array}$ \\
\hline Np: & $\begin{array}{l}\text { Antiochus inscription in the procession way in Nemrud Dagi (WALDMANN [1973], p. 70-71, with German translation in } \\
\text { p. } 76-7) ; 1^{\text {st }} \text { cent. BC. }\end{array}$ \\
\hline OS: & $\begin{array}{l}\text { Foundation of a Sarapis' cult in Locrian Opous (IG X 2, 1, 255; MERKELBACH [1973], p. 49-53; HORSLEY [1981], p. 29-32 } \\
\text { with English translation); Thessalonike, ca. } 1^{\text {st }} \text { cent. AD. }\end{array}$ \\
\hline $\mathrm{Ph}:$ & Dionysius' foundation in Philadelphia in Lydia (TAM V 3, 1539); $1^{\text {st }}$ cent. BC (?). \\
\hline SD: & $\begin{array}{l}\text { Delian aretalogy of Sarapis (IG XI 4, 1299; Greek text and English translation in MOYER [2011], p. 282-286); } 3^{\text {rd }} \\
\text { cent. BC. }\end{array}$ \\
\hline
\end{tabular}




\section{BIBLIOGRAPHY}

J. ALVAR, Romanising Oriental Gods. Myth, Salvation and Ethics in the Cults of Cybele, Isis and Mithras, Leiden/Boston 2008.

R. AsCOUGH, Paul's Macedonian Associations, Tübingen, 2003.

D. AUBRIOT, "L'invocation $\mathrm{au}(\mathrm{x}) \operatorname{dieu}(\mathrm{x})$ dans la prière grecque : contrainte, persuasion ou théologie ?", in BELAYCHE et al. (eds.) (2005), p. 473-490.

S.C. BARTON, G.H.R. HORSLEY, “A Hellenistic Cult Group and the New Testament Churches”, Jb. Antike Christent. 24 (1981), p. 7-41.

N. BELAYCHE, "L'évolution des formes rituelles: hymnes et mystèria", in L. BRICAULT, C. BONNET (eds.), Panthée: Religious Transformations in the Graeco-Roman Empire, Leiden, 2013, p. 17-40.

- et al. (eds.), Nommer les Dieux. Théonymes, épithètes, épiclèses dans l'Antiquité (Recherches sur les rhetoriques religieuses 5), Brepols, 2005.

J. BODEL, “' ‘Sacred dedications': a problem of definitions”, in J. BODEL, M. KAJAVA (eds.), Dediche sacre nel mondo Greco-romano. Diffusione, funzioni, tipologie, Roma, 2009, p. 17-30.

M. BOYCE, F. GRENET, A History of Zoroastrianism. Volume 3: Zoroastrianism under Macedonian and Roman Rule, Leiden, 1991.

L. BRICAULT, “Isis Myrionyme”, in C. BERGER, G. CLERC, N. GRIMAL (eds.), Hommages à Jean Leclant 3. Études Isiaques, El Cairo, 1994, p. 67-86.

J.-M. CARBON, V. PIRENNE-DELFORGE, “Beyond Greek ‘Sacred Laws' ”, Kernos 25 (2012), p. 163-182.

A. CHANIOTIS, "Reinheit des Körpers - Reinheit des Sinnes in den griechischen Kultgesetzen”, in J. ASSMANN, Th. SUNDERMEIER (eds.), Schuld, Gewissen und Person, Gütersloh, 1997 (Studien zum Verstehen fremder Religionen 9), p. 142-179.

-, “Acclamations as a Form of Religious Communication”, in H. CANCIK, J. RÜPKE (eds.), Die Religion des Imperium Romanum. Koine und Konfrontation, Tübingen, 2009, p. 199-218.

-, "Megatheism: the search for the almighty god and the competition of cults," in S. MITCHELL, P. VAN NUFFELEN (eds.), One God. Pagan Monotheism in the Roman Empire, Cambridge, 2010, p. 112-141.

C. CROWTHER, M. FACELLA, "New evidence for the ruler cult of Antiochus of Commagene from Zeugma”, in G. HEEDEMANN, E. WINTER (eds.), Neue Forschungen zur Religionsgeschichte Kleinasiens. Elmar Schwertheim zum 60. Geburtstag gewidmet, Bonn, 2003 (Asia Minor Studien 49), p. 41-80.

F.K. DÖRNER, T. GOELL (eds.), Arsameia am Nymphaios, Tübingen, 1963.

J. DUCHESNE-GUILLEMIN, "Iran and Greece in Commagene”, in ID. (ed.), Études Mithriaques. Acta Iranica IV, Leiden, 1978, p. 187-200.

H. ENGELMANN, The Delian Aretalogy of Sarapis, Leiden, 1975.

G. FOWDEN, The Egyptian Hermes: a historical approach to the late pagan mind, Princeton, 1993.

L. GAWLINSKI, The Sacred Law of Andania: a new text with commentary, Berlin/Boston, 2012.

J. GOEKEN, "Pour une rhétorique de la prière grecque", in GOEKEN (2010), p. 3-16 [= GOEKEN (2010a)]. 
-, "La prière et la tablette dans le mime IV d'Hérodas", in GOEKEN (2010), p. 109-124 [= GOEKEN (2010b)].

-, (ed.) La rhétorique de la prière dans l'Antiquité grecque, Turnhout, 2010 (Recherches sur les rhétoriques religieuses 15$)$.

-, Aelius Aristide et la rhétorique de l'hymne en prose, Turnhout, 2012 (Recherches sur les rhétoriques religieuses 15).

Y. GRANDJEAN, Une nouvelle arétalogie d'Isis à Maronée, Leiden, 1975.

F. GRAF, "Bemerkungen zur bürgerlichen Religiosität im Zeitalter des Hellenismus”, in M. WÖRRLE, P. ZANKER (eds.), Stadtbild und Bürgerbild im Hellenismus, Munich, 1995, p. 103-114.

Ph. A. HARLAND, Associations, Synagogues and Congregations. Claiming a Place in Ancient Mediterranean, Minneapolis, 2003.

M.B. HATzopoulos, La loi gymnasiarchique de Béroia, Athens, 1993.

A. HENRICHS, "The Sophists and Hellenistic Religion: Prodicus as the spiritual father of the Isis aretalogies, HSCPh 88 (1984), p. 139-158.

P. HERRMANN, K.Z. POLATKAN, Das Testament des Epikrates und andere neue Inschriften aus dem Museum von Manisa, Vienna, 1969.

G.H.R. HORSLEY, New documents illustrating early Christianity: a review of the Greek inscriptions and papyri published in 1976, North Ryde, 1981.

H.F.J.M. HORSTMANSHOFF, “Asclepius and temple medicine in Aelius Aristides' Sacred Tales”, in ID., M. STOL (eds.), Magic and Rationality in Ancient Near Eastern and Graeco-Roman medicine, Leiden/ Boston, 2004, p. 325-341.

M.-P. DE HOZ, Die Lydischen Kulte im Lichte der griechischen Inschriften, Bonn, 1999 (Asia Minor Studien 36).

-, "The regulations of Dionysius in the so-called lex sacra from Philadelphia in Lydia. Elevated strict moral code or current civil behavioural norms?", EA 50 (2017), in press.

K. HUMANN, O. PUCHSTEIN, Reisen in Kleinasien und Nordsyrien, Berlin, 1890.

S. JACQUES, “Le discours d'Isis et la deuxième prière de Lucius dans les Métamorphoses d'Apulée: deux hymnes d'inspiration arétalogique", in LEHMANN (2007), p. 507-520.

Y. LEHMANN, L'hymne antique et son public, Turnhout, 2007 (Recherches sur les rhetoriques religieuses 7).

L.R. LIDONNICI, The Epidaurian miracle inscriptions, Michigan, 1995.

V. LONGO, Aretalogie nel mondo greco I. Epigraphi e papiri, Genova, 1969.

H. MALAY, Greek and Latin Inscriptions in the Manisa Museum, Vienna, 1994 (Ergänzungsband TAM 19).

P. MARTZAVOU, "Isis aretalogies, initations, and Emotions: the Isis aretalogies as a source for the study of emotions", in A. CHANIOTIS (ed.), Unveiling Emotions: Sources and Methods for the Study of Emotions in the Greek World, Stuttgart, 2012, p. 267-291.

R. MERKELBACH, “Zwei Texte aus dem Sarapeum zu Thessalonike”, ZPE 10 (1973), p. 49-54.

I.S. MOYER, Egypt and the limits of Hellenism, Cambridge, 2011.

W.A. MEEKS, The Moral World of the First Christians, Philadelphia, Penn., 1986.

H. MÜLLER, “Ein Heilungsbericht aus dem Asklepieion von Pergamon”, Chiron 17 (1987), p. 193-233. 
P. MORAUX, Une imprécation funéraire à Néocésarée, Paris, 1959.

I.S. MORRIS, Egypt and the Limits of Hellenism, Cambridge, 2011.

E. NORDEN, Die antike Kunstprose I, Leipzig/Berlin, 1958 [1909].

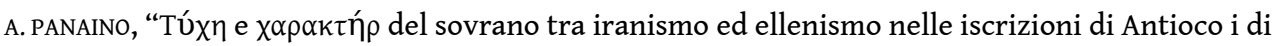
Commagene", in Gh. GNOLI, F.M. MUcCIOLI (eds.), Incontri tra culture, Milano, 2007, p. 117-131.

D. PAPANIKOLAOU, "The Aretalogy of Isis from Maroneia and the Question of Hellenistic Asianism", ZPE 168 (2009), p. 59-70.

-, "Sophistic Oratory and Styles in Roman Asia Minor: Hermogenes and the Tlos Sophist (TAM II. 174)", c\&M 63 (2012), p. 119-160.

L. PERNOT, La rhétorique de l'éloge dans le monde gréco-romain. Tome I : Histoire et technique, Paris, 1993.

-, "Le lieu du nom dans la rhétorique religieuse des Grecs", in BELAYCHE et al. (2005), p. 29-39.

-, “The Rhetoric of Religion”, in PERNOT (2009), p. 327-346.

- (ed.), New Chapters in the History of Rhetoric, Leiden/Boston, 2009a.

G. PETZL, Die Beichtinschriften Westkleinasiens, Bonn, 1994 (Epigraphica Anatolica 22).

Cl. PRÊTRE, Ph. CHARLIER, Maladies humaines, thérapies divines. Analyse épigraphique et paléographique de textes de guérison grecs, Villeneuve d'Ascq, 2009.

J. QUACK, “ 'Ich bin Isis, Die Herrin der beiden Länder', Versuch zum demotischen Hintergrund der memphitischen Isisaretalogie", in S. MEYER (ed.), Egypt-Temple of the Whole World. Studies in honour of Jan Assmann, Leiden/Boston, 2003, p. 319-365.

G.H. RENBERG, "Commanded by the gods": an epigraphical study of dreams and visions in Greek and Roman religious life. 1, Durham, NC, 2003.

RICIS: L. BRICAULT, Recueil des inscriptions concernant les cultes isiaques, Paris, 2005.

M. RICL, “Hosios kai Dikaios I : Catalogue des inscriptions”, EA 18 (1991), p. 1-70.

-, “Hosios kai Dikaios II : Analyse”, EA 19 (1992), p. 71-103.

-, “Hosios kai Dikaios : Nouveaux monuments", EA 20 (1992a), p. 95-100.

L.E. ROLLER, In Search of God the Mother: the cult of Anatolian Cybele, Berkeley et al., 1999.

W. SPEYER, Bücherfunde in der Glaubenswerbung der Antike, Göttingen, 1970.

F.T. VAN STRATEN, “Daikrates' Dream: a votive relief from Kos, and some other kat' onar dedications", BABesch 31 (1976), p. 1-38.

J.H.M. STRUBBE, Arai epitymbioi. Imprecations against Desecrators of the Grave in the Greek Epitaphs of Asia Minor: a catalogue, Bonn, 1997.

M. тоттI, Ausgewählte Texte der Isis- und Sarapis-Religion, Hildesheim, 1985.

V.F. VANDERLIP, The Four Greek Hymns of Isidorus and the Cult of Isis, Toronto, 1972 (American Studies in Papyrology 12).

H.S. VERSNEL, Inconsistencies in Greek and Roman Religion. 1. Ter Unus: Isis, Dionysos, Hermes, Three Studies in Henotheism, Leiden, 1990. 
J.L. VIX, "Les épiclèses d'Asclépios dans les discours XXX et XXXIII d'Aelius Aristide", in BELAYCHE et al. (2005), p. 557-566.

-, L'enseignement de la rhétorique au II siècle ap. J.-C. à travers les discours 30-34 d'Aelius Aristide : en logois kai mathēmasin kai epainois trapheis, Turnhout, 2010.

J. WAGNER, G. PETZL, "Relief- und Inschriftenfragmente des kommagenischen Herrscherkultes aus Ancoz", in G. HEEDEMANN, E. WINTER (eds.), Neue Forschungen zur Religionsgeschichte Kleinasiens. Elmar Schwertheim zum 60. Geburtstag gewidmet (Asia Minor Studien 49), Bonn, 2003, p. 85-96.

H. WALDMANN, Die kommagenischen Kultreformen unter König Mithridates I Kallinikos und seinem Sohne Antiochos I, Leiden, 1973.

O. WEINREICH, Stiftung und Kultsatzungen eines Privatheiligtums in Philadelpheia in Lydien, Heidelberg, 1919 (Sitz.-ber. Heidelberg Akad. d. Wiss., phil.-hit. Kl. 16).

K. ZAMFIR, "Once more about the origins and background of the New Testament Episkopos", Sacra Scripta X.2 (2012), p. 202-222.

-, "The Community of the Pastoral Epistles - A Religious Association", in V. GABRIELSEN, Ch. A. THOMSEN (eds.), Private Associations and the Public Sphere, Copenhagen, 2015, p. 206-240.

\section{NOTES}

1. The analysis made in this paper focuses on content, not stylistic elements of the religious discourse. For the analysis of this type of elements as part of rhetoric see the work of the French school of Strasbourg, especially PERNOT (1975, 1993 [esp. I, 224-238], 2009); and GOEKEN (2010) in his introduction to his edited volume, as well as many of the papers included there. See also the ancient works of Theon, Alexander or Menander on rhetorical exercises for this interpretation of the term rhetoric.

2. Since this paper does not involve theoretical questions about religious terminology, and since there are still no alternative expressions that fit the complex reality we refer to when we talk about certain religious matters, I will use traditional expressions such as "oriental cults/ religions" or "sacred texts", which are still the most clear conventional terms used to express what I want to designate. These terms are widely understood by all colleagues dealing with religious matters, who are of course aware of all the modifications that these expressions have experienced in their meaning thanks to a better knowledge of Greek and Roman religion. With "oriental cults" I understand those cults that, originating in the eastern Mediterranean, underwent a thorough-going transformation in the process of adapting themselves to Hellenistic-Roman culture (for this definition and comment on the terminological question see ALVAR [2008], p. 10). On the conventional though clear and broad use of the term "sacred" cf. BODEL (2009). The expression "religious discourse" is used here in the sense of communication uttered in a religious context or with a religious content. Cf. PERNOT (2009), p. 329: "What we call religious discourse consists, first of all, in speaking about the gods. Discourse about the gods includes, notably, narration of the god's deeds and eulogy of his powers [...] preaching [...] exhorting an audience either to embrace a religion they do not yet know or to persevere in the beliefs they already hold [...]; naming (the gods) and designation [...]."

3. IG XII 3, 421f.; XII 3, Suppl. 1333-1348. Cf. GRAF (1995), p. 107-112 with comment and further bibliography.

4. IG XI 4, 1299; ENGELMANN (1975); MORRIS (2011), p. 282-286, comment in p. 242-207. 
5. HUMANN - PUCHSTEIN (1890), p. 262-278; NORDEN (1909), p. 140-146; OGIS 383; WALDMANN (1973), p. 59-79.

6. For A see DÖRNER (1963), p. 40-59; WALDMANN (1973), p. 82-100; for Anz see the reconstruction of the text established by WAGNER - PETZL (2003), p. 91-96 with the different fragments found and the parallels of the texts from the other cult sites. For further bibliography and more recentlydiscovered fragments from Zeugma see CROWTHER - FACELLA (2003). Cf. SEG 53.1762. Since the inscriptions from the other temenos sites, including the new discoveries, and from the hierothesion in Arsameia on the Euphrates match in a great part N, Np, A, or Anz, or do not add any new information to the topic of this paper, only reference to the mentioned inscriptions of the dossier will be discussed.

7. On the very much discussed question of Antiochus' texts as evidence of an Asianic rhetoric style see, with earlier bibliography, PAPANIKOLAOU (2012), who concludes that the rhetoric of Antiochus's inscriptions was a rhetoric cultivated throughout the Greek-speaking world, and that it represents the Hellenistic continuation of a tradition of oratory established very likely by Gorgias (p. 141, 152).

8. TAM V 3, 1539, with references to previous editions. Cf. especially WEINREICH (1919), BARTONHORSLEY (1981), CHANIOTIS (1997), p. 159-162, 172f.; ROLLER (1999), p. 194-6 (on the relationship between the Phrygian Agdistis, guardianship of the community, and the aim to correct moral behaviour that is attested in Phrygia in the first three centuries AD); HARLAND (2003), p. 30-31, 33, 70-71 (for household connections in relationship to this and other associations). Though the term "sacred law" is conventionally used for documents dealing with religious regulations, and specifically for this one, the term "law" will be avoided here because of its inadequacy and inaccuracy, as some scholars have set forth. See especially CARBON - PIRENNE-DELFORGE (2012), with further bibliography.

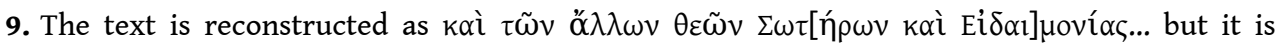
possible that there was no second kaí, and that Eudaimonia and following gods were in fact the Theoi Soteres.

10. See PERNOT (1993), p. 216-218, with notes 502, 503 for references to ancient authors.

11. GRANDJEAN (1975) (SEG 26.821; BRICAULT, RICIS 114/0202). From now on IM. See PAPANIKOLAOU (2009) on stylistic features of this aretalogy and its belonging to a specific school of writing that flourished during the Hellenistic times, and to which also Antiochus' inscriptions belonged.

12. See GOEKEN (2012) for earlier evidence in ancient literature that could be considered prose hymns, beginning with Agaton's encomium of Eros in Plato's Symposion.

13. See especially the treatment of this subject by PERNOT $(1975,2009)$; on rhetoric of the Greek prayer see GOEKEN (2010) with further bibliography.

14. There is a wide literature on Isis aretalogies and hymns. See especially FESTUGIÈRE (1949); GRANDJEAN (1975); VANDERLIP (1975); HENRICHS (1984), and infra note 100; for a collection of the Greek texts see тоTтI (1982); in Spanish translation, MUÑIz (2006). For a state of the art on the discussion on the convenience and accuracy of defining these texts as hymns or aretalogies, or of using one or the other term depending on the text, see MUÑIZ (2006), p. 34-39. On the concept of aretalogy and a collection of epigraphic and papyrological aretalogies see LONGO (1969). I will not discuss this question here, and will mention in general Isis' hymns and aretalogies, though accepting the term aretalogy for Maroneias (IM). Some of Aristides' hymns, and specially his hieroi logoi, are also aretalogies, in the sense that they praise the god Asclepius relating his miracles and benefactions.

15. I will mention for instance the funerary inscriptions of Posidonius in Halicarnassus (Syll. ${ }^{3}$, 1044; LSAM 72; SEG 15.637; III $3^{\text {rd }}$ cent. BC) and of Neocaesarea (MORAUX [1959]; SEG 18.561; STRUBBE [1997], no. 155; II $2^{\text {nd }}$ cent. AD); the Ephesian decree designating the month of Artemision as holy (IEphesos 163; 162/4 AD) or the mythological narrative written by a Lycian rhetor and publicly 
exposed in Sidyma with official agreement (TAM II 174; second half of the $2^{\text {nd }}$ cent. AD). For the topos of divine epiphany and miraculous action there is plenty of evidence, especially in narratives concerning the healings of Asclepius.

16. See MOYER (2011), p. 161-164 on the importance of the genealogy of the priest in relation to Egyptian tradition.

17. As in the case of Apollonius in Delos, the inherited character of Antiochus' kingship (N 24:

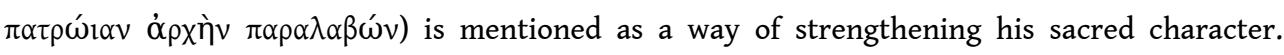
Cf. A 15-16.

18. IG X 2, 1, 64 (Thessalonica, 74/5 AD, saved by Theos Hypsistos); IG XII 1, 742 (Kamiros, saved by Sarapis); TAM V1, 179b, 194/5 AD (saved by megas Zeus eg didymon dryon); IStraton. 512 (2 ${ }^{\text {nd }}$ cent. AD, saved by Hecate); IG XIV 1030 (Roma, $3^{\text {rd }}$ cent. AD, saved by Zeus Helios Megas Sarapis). See also the iama from the Asklepieion of Pergamum written down by a Rhodian visitor (PRÊTRE CHARLIER [2009], no. 20. Cf. MÜLLER [1987], with detailed comment; $2^{\text {nd }}$ cent. AD): غ่v $\alpha \rho \gamma \tilde{\omega} \varsigma \dot{\varepsilon} \kappa$

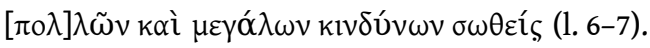

19. Asclepius orders Aristides many $\pi \alpha \rho \alpha ́ \delta \circ \xi \alpha$, things contrary to expectation, sometimes almost inhuman and exaggerated prescriptions, as he tells us in his Hieroi Logoi. See HORSTMANSHOFF (2004), p. 329-30; cf. examples in MÜLLER (1987), p. 225, n. 239.

20. Cf. for a collection of these texts PRÊTRE - CHARLIER (2009). For a collection of the Epidaurian iamata see LIDONNICI (1995); among the many studies on the different aspects (composition and narrative technique, illnesses and healings, dreams, psychology...) of iamata see MARTZAVOU (2012) with further bibliography.

21. See reference to the divine appearing in IM 10; cf. HIs 1.34. In a honorific decree from Stratonicea (IStraton. 512) to Hecate, the goddess is said to protect the demos, who has been saved from perils and turned free and autonomous, and lord of great goods having Hecate always by its

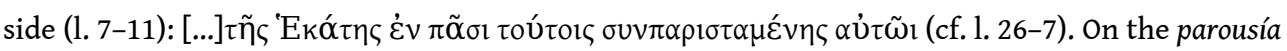
of Artemis in Ephesus cf. IEphesos 24B, and infra note 57.

22. See PERNOT (1993), p. 220, with n. 521 for references of ancient writers to divine manifestations.

23. Cf. Menander 2.368-377f. on the praise to the emperor for comparison.

24. On the importance of eusebeia cf. GRAF (1995), p. 104 with n. 10. For further instances cf. IStraton. 512, 1. 5, cf. 1. 21.

25. See VIX (2010), p. 301-313.

26. See MOYER (2011), p. 165-175 for an Egyptian tradition of this topos.

27. On divine letters see SPEYER (1970), p. 17-19, 23-42.

28. Cult foundations motivated by divine command before Hellenistic times are, among others, the foundation of the cult of Asclepius in Athens by Telemachus ca. 400/390 BC (IG II ${ }^{2} 4960 \mathrm{ab}+$ 4961), or the foundation of a cult in Priene for the hero Naulochus as a god (IvPriene 196, $4^{\text {th }}$ cent. BC). On foundation of associations because of divine order, often through a dream, see ASCOUGH (2003), p. 34-42, with many examples. On divine order in general, mostly through dreams, cf. vAN STRATEN (1976), RENGSBERG (2003) and, for its special relevance in Egyptian cults, MOYER (2011), p. 165-175.

29. SD 45. Cf. also a particular type of aretalogies, the so-called confessions of Lydia and Phrygia, where the sinner is forced by the god through a dream to make public his sin and divine chastisement by writing it down on a stele in order to appease the god and make propaganda of his power (PETZL [1994], no. 3, 11, 47, 57, etc.).

30. For the topos in Aelius Aristides see vIX (2010), p. 308-310.

31. Cf. supra section 2 . Though not directly related to the foundation's document, see also the reference in SD to the bill ( $\beta 1 \beta \lambda_{1} \delta$ íov) where the announcement of land for sail was written ( 20 ; 57-58). Cf. the importance of the letter in the aforementioned document concerning the 
foundation of a cult to Sarapis in Opus. In this case the god is supposed to be the author of the written text, in the former, he is directly responsible.

32. The same relation between written text and eternity is very well evidenced in funerary texts of Hellenistic and Roman times, where the written word is mentioned more and more. $\mathrm{Cf}$. the

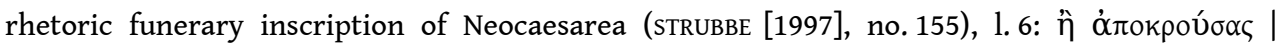

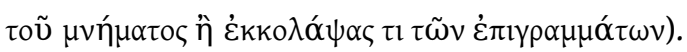

33. For the topos see GRANDJEAN (1975), p. 38-42.

34. Cf. MOYER (2011), p. 164 for the relation of this information to Egyptian priestly tradition.

35. See GOEKEN (2010a), p. 118-120.

36. The relation to other gods is one of the elements PERNOT includes in the religious rhetoric of the hymns as a "thème annexe", comparable to the argument of comparison in the praise of mortals (1993, p. 232-233).

37. On the gods of Artemidorus and the divine abstractions see GRAF (1995), p. 109-110.

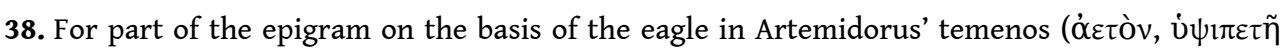

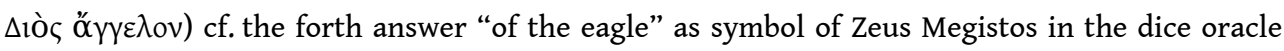

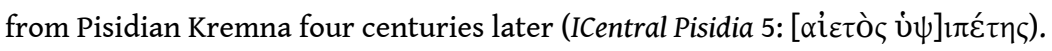

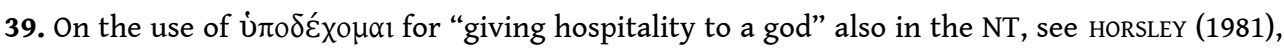
p. 29-32.

40. On Antiochus' new syncretistic cult see BOYCE - GRENET (1991), p. 321-337.

41. On Helius and Zeus as gods of justice see STRUBbe (1997), p.114-115 (comment on the

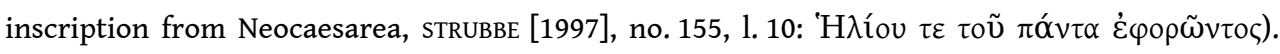
This aspect of Helios, already attested in Od.12.323, turns to be a main element in the development of the god as a cult god and especially as a henotheistic god in Greco-Roman times.

42. For the zodiacal interpretation of the sculpture of the lion set up in the sacral space, and how the symbiosis of Greek and Iranian gods (and also Semitic religious conceptions) was established in this cult see BOYCE - GRENET (1991), p. 323-328.

43. For a thoroughly comment on the gods of Dionysius' statute see WEINREICH (1919), p. 8-54.

44. Cf. IG XI 2. 105, 108-113, 115, etc. (Delos, $3^{\text {rd }}-1^{\text {st }}$ cent. BC); IEphesos 1398 ( $1^{\text {st }}$ cent. AD); IHeraclea Pont. 69.

45. See GRAF (1995), p. 112-3 for the importance of Agathos Daimon and Agathe Tyche as personal gods in Hellenistic times, and PANAINO (2007) for the tyche of Iranian kings.

46. The importance of Memory as a subject in Hellenistic and Roman epitaphs is well known. Cf. for instance the already mentioned rhetoric epitaph of Neocaesarea (STRUBBE [1997], no. 155, 1.18).

47. On "oriental" gods see supra note 2 .

48. Cf. GRAF (1995) on the Hellenistic cult of divine abstractions.

49. Using a term coined by VERSNEL in 1990. On the sense of the term henotheistic such as it is used here see also VERSNEL (1990), p. 35-38.

50. For the relation of the main god to other gods in Aristides' hymns, cf. GOEKEN (2012), p. 129130.

51. The concern with patrioi nomoi is attested also in other sacred texts. Cf. for instance the answer of the oracle to Dionysius in Halicarnassus, that he shall worship the gods as his ancestors

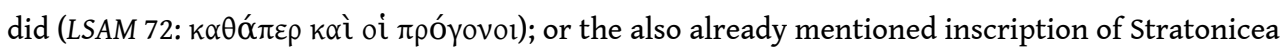
(IStraton. 512), a decree concerning honors to Hecate and her sanctuary, where it is said that the

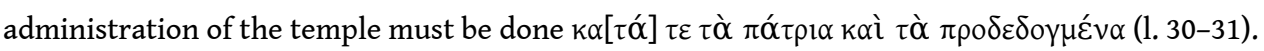

52. Cf. PERNOT (1993), p. 231-232 for the reference to the tradition of the cult as an argument of authority. This author mentions as an example the reference in the aretalogy of Isis from Maroneia to the sanctuary consecrated to the goddess (IM 34-40). 


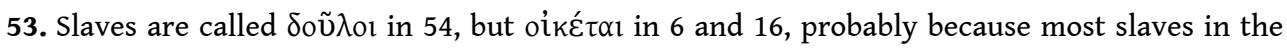
community were household slaves.

54. Cf. the lex sacra of Andania (LSCG 65, 1. 7-8; $91 \mathrm{BC}$ or maybe $23 \mathrm{AD}$; cf. GAWLINSKI 2012). The insistence on access to everyone is also clear in some inscriptions of Stratonicea, where men, women, slaves and free persons and foreigners are explicitly said to have access to Zeus and Hera festivals, though the place to join is different for men and women (IStraton. 172, 1. 7-10, cf. 137, 1. 28-36). Cf. BELAYCHE (2013), p. 37-39 for these inscriptions and the Egyptian tradition of inviting to the divine banquet. See also the Ephesian decree declaring sacred the whole month Artemision (IEphesos 24B). Greeks and barbarians are both worshippers of the goddess and in Greek and barbarian areas shrines and altars have been built for her because of her bright apparitions (1. 814).

55. In Posidonius foundation in Halicarnassus ( $L S A M 72,3^{\text {rd }}$ cent. $B C$ ), the succession rights are same for men and women (1. 3-4, 13-14, cf. 42).

56. MEEKS (1986), p. 129, who also points out that Paul himself urged Christians to be aware of, and respect, social strata assuming each one his role.

57. In the same way, the demos of Stratonicea (IStraton. 512) was saved of big perils because of his

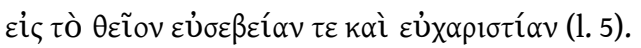

58. On the relation of these clauses to civil laws cf. DE HOZ (2017).

59. Cf. the same differences in the mentioned rhetoric funerary inscription of Neocaesarea

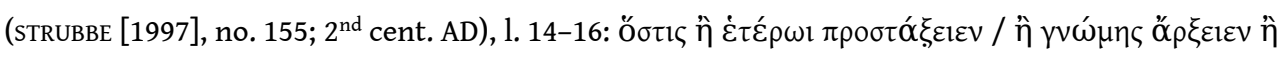

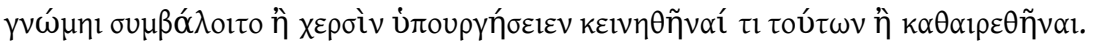

60. LSCG supp. 108, 1. 4ff. (Rhodes, mid. $1^{\text {st }}$ cent. AD); LSCG 139 (Lindos $2^{\text {nd }}$ cent. AD); LSCG supp. 59 (Delos $2^{\text {nd }}$ cent. AD); IG XII Suppl. 23 = LSCG supp 82 (Mytilene, Imp. times); LSCG 55 = CMRDM I 13, 1. 11-12, 26 (Attica $1^{\text {st }}$ cent. AD); LSCG supp. 86 (Lindos, $3^{\text {rd }}$ cent. AD); LSCG supp. 91 (Lindos, $3^{\text {rd }}$ cent. AD).

61. Indirectly, there is also a similitude with the Isis hymns in the concern on women and the

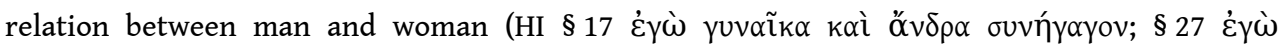

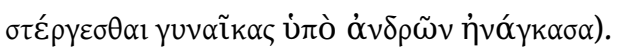

62. Cf. MITCHELL II (1993), p. 25-6.

63. This relation appears in other epigraphic sources, such as Beroia's law in the $2^{\text {nd }}$ century BC (HATZopoulos [1993], 1. 26-29); IPriene 46 (and p. 310, 100 BC), 1. 11-12. On Hosios kai Dikaios, see RICL (1991, 1992, 1992a).

64. In some cases a false oath must be undone in order to get the forgiveness of the god (BI 34 , 54). As sacrilegious as a false oath is the not justified use of scepters or of written curses (for the use of these elements as judicial appeals cf. BI 17, 20, 44, 58, 69).

65. On the oath mentioned in the lex sacra from Andania and other oaths taken in religious contexts see GAWLINSKI (2012), p. 99-102.

66.

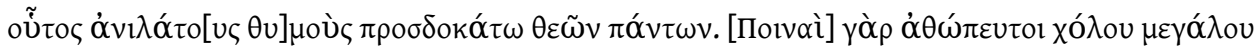

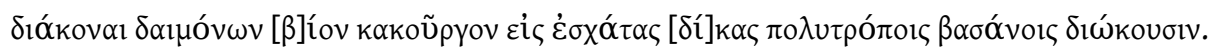

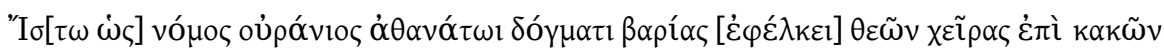

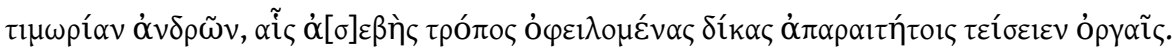

67. Cf. also some funerary texts such as the already mentioned epitaph of Neocaesarea (STRUBBE [1997], no. 155) or other imprecations from Asia Minor (sTRUBBE [1997]).

68. Cf. even a goddess Ara in the funerary inscription of Neocaesarea, and the Poinai in the imprecation in Antiochus' stele (A and Anz 221-224).

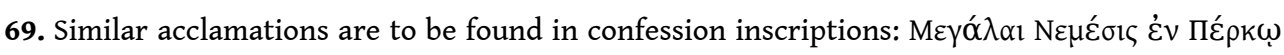

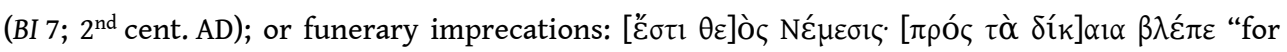


there is a goddess Nemesis; she watches over justice", MERKELBACH - STAUBER 16/54/1; cf. 16/31/09, $16 / 32 / 12$.

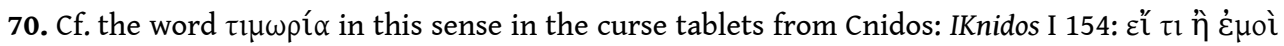

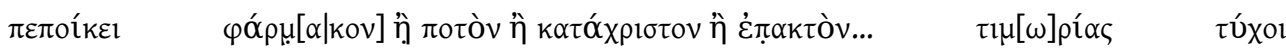

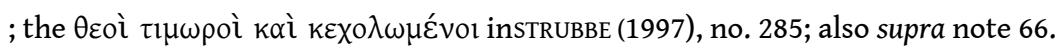

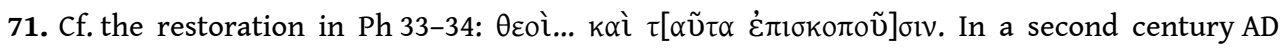
imprecation from Chalkis in Euboia (IG XII Suppl.196, 1179, cf. 955), the Eriniai are invoked as

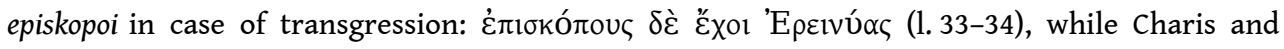

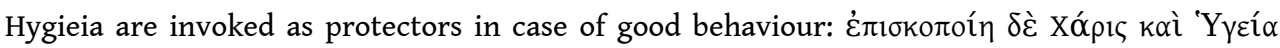
(1. 40-41).

72. ASCOUGH (2003), p. 162-166 with numerous references; ZAMFIR (2015), p. 222-226. In general on the term, ZAMFIR (2012), p. 202-22. For the appearance of this term referred to gods in literary sources cf. WEINREICH (1919), p. 61.

73. Cf. MAMA VIII 193 (Licaonia). In NT the term is used for the master of the household where Christians gather in: Lc. 22.11; Mc. 14.14.

74. For the use of the term $\varphi \nu \lambda \alpha$ ó $\sigma \varepsilon เ v$ referring to a god that takes care of a person or group

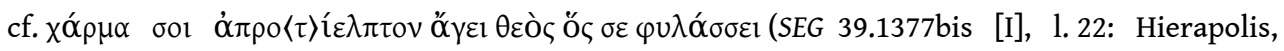
Phrygia).

75. PETZL (1994). The explicit term "̌ $\xi \varepsilon v \pi \lambda$ ov in op.cit. no. 120 (cf. 106, 111, 112, 120, 121) is good evidence of this aim in confessions, where it is usually stated that the god has ordered the sinner to write down the event on a stele (see also DE HOZ [1999], p. 123). The importance of the example is stated also in Antiochus' stele, where the king puts himself as an example to follow, saying that the hierothesion and the nomos are an example for future generations (N. 212-222).

76. For a collection of texts where public demonstration of the power of the god is an important element see LONGO (1969).

77. PERNOT (2005, p. 29-39; 2009, p. 233-237) indicates different types of names and epiclesis attributed to gods, among them local and functional. For ancient Greek comments on this topos cf. Arist. Rh. II, 1400b 18-28, 1401a 13-25; Theon, Progym. 111, 3-11; Menander 1.357, 9-11. On acclamations see CHANIOTIS (2010).

78. For this type of epitheta attributed to the Lydian gods and their significance in confession inscriptions see DE HOZ (1999), p. 117; in general, CHANIOTIS (2010).

79. On Isis sovereignty see JACQUES (2007), 517-519.

80. Cf. vix (2005), p. 561-563.

81. For the possibility of this being a reference to the Pergamene king Eumenes cf. WEINREICH (1919), p. 9-10. I think that this term here is not a cult epithet but an attribute of Zeus as giver of norms (see DE HOZ [2017], note 3).

82. On the epithet eumenes dedicated to Asclepius by Aristides see VIX (2005), p. 561.

83. On the epithet soter dedicated to Asclepius by Aristides see VIX (2005), p. 558-59.

84. On polyonymia and ritual scruples see PERNOT (2005), p. 37-38. As this author says, these arguments are well known in poetic traditional hymns, but they are adopted and expanded in sacred texts from Hellenistic and Roman times. Cf. Menander 2.445, 28-30; 446, 8-10.

85. zogRAFOU (2005), p. 531-542, esp. 534-5, with references of Artemis Phosphoros Soteira.

86. Cf. Alexand. 4.31. For Isis polyonymos, cf. BRICAULT (1994).

87. IRhod.Per. 506 ( $2^{\text {nd }}$ cent. AD); IEphesos $1247 \mathrm{~B} ; 31003^{\text {rd }} / 4^{\text {th }}$ cent. AD); SEG 29.731(14) (Chersonesos, $2^{\text {nd }} / 3^{\text {rd }}$ cent. AD); IGLSyr 4.1279 (Laodikeia). Especially frequent is the acclamation

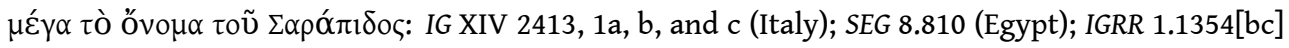
(Nubia). Cf. L. ROBERT, Hellenica X, p. 84-89, 299.

88. Cf. PERNOT (1993), p. 235 for other examples in Aristides' hymns. 
89. GOEKEN (2012), p. 131-136, also for other names and epiclesis in Aristides' hymns.

90. Cf. the prayer in the final verses of Cleanthes' hymn (401-408) asking for intelligence and protection against ignorance; in the final verses of Aratus hymn (424-426), so that the Muses inspire his work on the stars; at the beginning of Isis' aretalogy of Maroneia (IM) or in some of Aristides' hymns such as the hymn to Zeus, Athena (also at the end) or the hymn to Serapis ( $\$ 14$; and at the end § 34 ), asking for acceptance of the hymn and protection in the future, as also at the end of the hymn to the Asklepiadai.

91. See vix (2012), p. 308-311.

92. Cf. supra, p. 206 for other examples.

93. See AUBRIOT (2005), p. 473-490 for having persuasion as a main objective of the invocation to gods in prayers.

94. Cf. supra for the importance of abstractions in general in Hellenistic and Roman times, and also for the roll of abstractions in the foundation of Artemidorus of Perge in Thera.

95. WEINREICH (1919), p. 51-54.

96. WEINREICH (1919), p. 54-62 (spread along his comment on the different norms).

97. Cf. PERNOT (2005), p. 237, for the idea that the trend to worship a supreme god owes much to the Stoicism of the people who popularized it. I would say that this Stoicism owes also much to the expansion of oriental religions where that henotheism is already alive. For the pantheistic conception of the world in Aristides' hymns cf. GOEKEN (2012), 102.

98. See especially MOYER (2011), p. 142-207 for the Delian aretalogy; PANAINo (2007) for Antiochus' inscriptions, especially for the intercultural Greek-Iranian interpretation of concepts such as

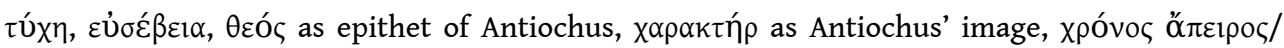

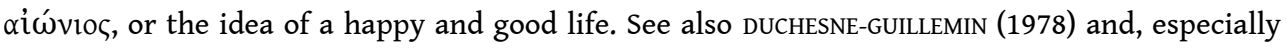
on the Iranian-Greek cult of Antiochus, BOYCE - GRENET (1991), p. 321-349; 323 on the concept of Tyche. On the Aegyptian cultural elements of Greek Isis hymns and aretalogies see for instance VANDERLIP (1972), GIANGRANDE (1975), esp. p. 12-15, FOWDEN (1986), p. 45-51, or QUACK (2003), p. 31924. Cf. HENRICHS (1984).

\section{ABSTRACTS}

In Greek inscriptions on cult foundations and regulations from the Hellenistic period onwards it is possible to see the development of an especial religious discourse that includes ancient and new hymnic elements, in addition to new topoi that do not belong to the Hymn tradition. This new religious discourse develops incorporating new features of Greco-Roman religion, strongly influenced by oriental cults, and at the same time well aware of the new philosophical trends that very much pervaded religion at this time. Some sacred inscriptions from the third century $\mathrm{BC}$ onwards show precedents of elements well attested in the sacred literary prose of the second century AD. In this paper, the main topoi that constitute this new religious discourse will be analyzed looking specifically at the topoi concerning the founder of the sacred institution or norms, the god or gods worshipped and the worshippers, and also the topoi concerning the content of the foundation norms and the resources used to force the observance of the norms.

À partir de la période hellénistique, les inscriptions grecques concernant des fondations ou des régulations cultuelles permettent de saisir le développement d'un discours religieux particulier 
qui inclut des éléments hymniques, anciens et modernes, ainsi que de nouveaux topoi qui ne relèvent pas de la tradition hymnique. Ce nouveau discours religieux se développe en intégrant de nouveaux traits de la religion gréco-romaine, fortement influencés par des «religions orientales", tout en étant conscient des nouvelles tendances philosophiques qui infusent la religion de ce temps. Depuis le $\mathrm{III}^{\mathrm{e}}$ siècle avant notre ère, au moins, des inscriptions "sacrées » attestent des précédents pour des éléments bien présents dans la prose littéraire sacrée du II siècle de notre ère. La présente étude analyse les principaux topoi de ce nouveau discours religieux, en se penchant tout particulièrement sur ceux qui concernent le fondateur de l'institution sacrée ou de la norme instituée, le dieu ou les dieux honoré(s) et les acteurs du culte, ainsi que les topoi concernant le contenu des règles de fondation et des ressources invoquées pour les faire respecter.

\section{AUTHOR}

\section{MARÍA-PAZ DE HOZ}

Universidad de Salamanca

mphoz@usal.es 